\title{
British Art Studies
}

\section{November 2019}


British Art Studies

Issue 14, published 29 November 2019

Cover image: James Richards, on the side of the disease and not the cure, 2019 .. Digital image courtesy of James Richards.

PDF generated on 14 April 2022

Note: British Art Studies is a digital publication and intended to be experienced online and referenced digitally. PDFs are provided for ease of reading offline. Please do not reference the PDF in academic citations: we recommend the use of DOIs (digital object identifiers) provided within the online article. These unique alphanumeric strings identify content and provide a persistent link to a location on the internet. A DOI is guaranteed never to change, so you can use it to link permanently to electronic documents with confidence.

Published by:

Paul Mellon Centre 16 Bedford Square London, WC1B 3JA https://www.paul-mellon-centre.ac.uk

In partnership with:

Yale Center for British Art 1080 Chapel Street New Haven, Connecticut https://britishart.yale.edu

ISSN: 2058-5462

DOI: $10.17658 /$ issn.2058-5462

URL: https://www.britishartstudies.ac.uk

Editorial team: https://www.britishartstudies.ac.uk/about/editorial-team Advisory board: https://www.britishartstudies.ac.uk/about/advisory-board

Produced in the United Kingdom.

\section{Ajoint publication by}




\section{Contents}

"The Sense of Nearness":

Harriet Hosmer's Clasped Hands and the Materials and Bodies of NineteenthCentury Life Casting, Katherine Fein 


\section{and Bodies of Nineteenth-c}

\section{Abstract}

In 1853, Robert Browning and Elizabeth Barrett Browning sat for a plaster life cast of their intertwined right hands. Previous accounts of this sculpture have interpreted it as a sentimental testament to the poets' famous romance, neglecting the complexity of the casting process. This article looks anew at Hosmer's Clasped Hands by combining close examination of the plaster and bronze versions with historical records of life casting and recent theoretical approaches to the body. This analysis draws attention to the multifaceted negotiations among artistic materials and human hands that conspired to produce this sculpture. In doing so, it troubles widely held assumptions about the indexicality of life casts, proposing instead a dynamic set of relationships better described as nearness.

\section{Authors}

Katherine Fein is a PhD student in the Department of Art History and Archaeology at Columbia University, New York.

\section{Acknowledgements}

Many thanks are due to Tim Barringer, Caitlin Beach, Zoë Dostal, Meredith Gamer, Elizabeth Hutchinson, and the anonymous peer reviewers for their thoughtful feedback on this project. Previous versions of this article were presented at the Cambridge-Columbia Graduate Symposium in the History of Art and at a conference jointly sponsored by the Paul Mellon Centre for Studies in British Art and the National Portrait Gallery-I am grateful for the valuable input provided by fellow participants and generous audiences at these events. Finally, thank you to the staff of Harvard University, in particular Jeremy Guillette and Diana Carey, who organized the threedimensional scan of Clasped Hands which enriches this article. 


\section{Cite as}

Katherine Fein, "“The Sense of Nearness":

Harriet Hosmer's Clasped Hands and the Materials and Bodies of NineteenthCentury Life Casting", British Art Studies, Issue 14, https://dx.doi.org/

10.17658/issn.2058-5462/issue-14/kfein 
Elizabeth Barrett Browning encountered daguerreotypes shortly after they debuted in 1839. In an 1843 letter, she described her fascination with the new photographic medium:

It is not merely the likeness which is precious in such cases-but the association, and the sense of nearness involved in the thing, the fact of the very shadow of the person lying there fixed for ever! It is the very sanctification of portraits I think ... that I would rather have such a memorial of one I dearly loved, than the noblest Artist's work ever produced. 1

Ten years after writing this letter, during which time she met and married Robert Browning, Barrett Browning posed with her husband for a related form of portraiture: a plaster life cast of their right hands by sculptor Harriet Goodhue Hosmer (Figs. 1 and 2). Barrett Browning's description of daguerreotypes could also apply to life casts, which similarly capture likeness, act as memorials to loved ones, and bridge spatial and temporal distance through direct physical relationships. Although her articulation of "nearness" might be dismissed as Victorian sentimentality, it also suggests a framework for describing the complex interactions among individuals and materials that conspire to produce both daguerreotypes and life casts.

\section{Figure 1.}

Harriet Hosmer, Clasped Hands of Robert and Elizabeth Barrett Browning, 1853 , plaster, $8.3 \times 21 \times 10.8 \mathrm{~cm}$. Collection of the Schlesinger Library on the History of Women in America, Radcliffe Institute for Advanced Study, Harvard University, Cambridge, MA. Digital image courtesy of Harvard University | Photo: Kevin Grady. 


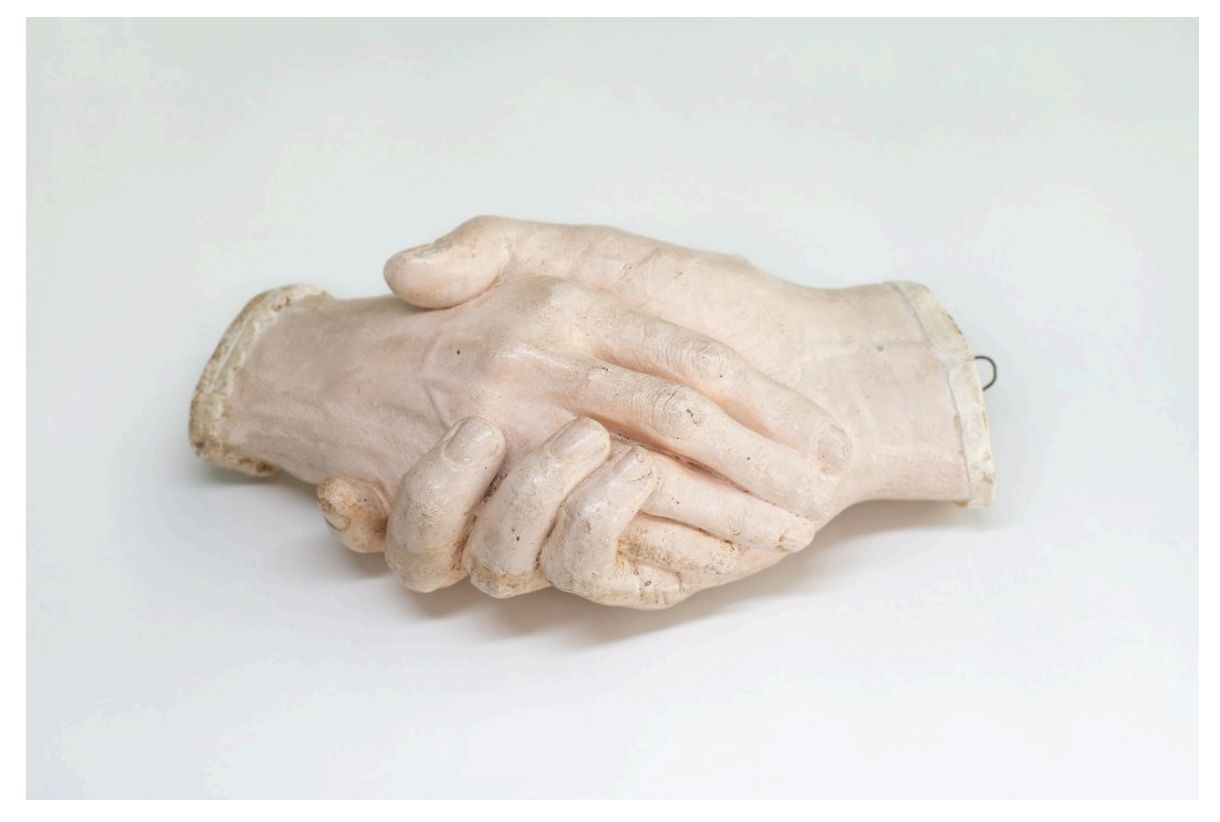

Figure 2.

Harriet Hosmer, Clasped Hands of Robert and Elizabeth Barrett Browning, 1853, plaster, $8.3 \times 21 \times 10.8 \mathrm{~cm}$. Collection of the Schlesinger Library on the History of Women in America, Radcliffe Institute for Advanced Study, Harvard University, Cambridge, MA. Digital image courtesy of Harvard University | Photo: Kevin Grady.

What Barrett Browning deemed nearness has been theorized as indexicality since the turn of the twentieth century, when semiotician Charles Sanders Peirce identified indexes as signs that bear physical connections to their referents. $\stackrel{2}{2}$ Artists, critics, and scholars have extensively explored this commonality of photography and cast sculpture. Susan Sontag, for example, wrote that a photograph is "not only an image" or "an interpretation of the real" but also "a trace, something directly stenciled off the real, like a footprint or a death mask". ${ }^{3}$ Rosalind Krauss connected photography and body casts in an influential 1977 essay, elaborating a notion of indexicality premised on contingency: "The indexical presence of either the photograph or the body-cast demands that the work be viewed as a deliberate shortcircuiting of issues of style. Countermanding the artist's possible formal intervention in creating the work is the overwhelming physical presence of the original object". ${ }^{4}$ Krauss privileged the object at the expense of the artist, the latter asserting herself only to emphasize her absence.

Understanding cast sculpture through the lens of indexicality thus results in a sense of unity: the conjunction of the cast and the object. Where Barrett Browning marveled at how daguerreotypes bring someone or something near, Krauss argued for the continued "physical presence" of that body or thing within a photograph or cast. Krauss' commitment to the object's presence precludes artistic or material intervention. In contrast, Barrett 
Browning's notion of nearness - which recognizes the intimacy between object and representation while preserving their distinction-makes room for negotiation among multiple agents, including the artist.

To expand the investigation into these ontological issues, or to circumvent them entirely, many historians of photography have moved "beyond the index" (to quote a recent compilation of essays). ${ }^{5}$ Generative theoretical literature has also emerged around death masks, probing the liminality of these objects and the relationship between figural sculpture and mortality. $\frac{6}{6}$ Furthermore, scholars have researched life casting in specific historical eras, using archival sources to recover lost techniques, but the practice of life casting in the United States and Europe during the nineteenth century remains comparatively understudied. $\underline{\underline{Z}}$ Inspired by this innovative work as well as recent ecocritical, feminist, and new materialist scholarship, this article attends to the individuals, materials, and processes involved in the making of one particular life cast: Hosmer's Clasped Hands of Robert and Elizabeth Barrett Browning. In doing so, it questions indexicality as the dominant interpretive frame for life casts, proposing instead a dynamic, vital, and complex set of relationships better described as nearness.

Ten versions of Hosmer's sculpture are known to exist: the original plaster cast, which she produced in Rome in 1853, an undated second plaster version, and eight versions in bronze, likely cast before $1896 . \stackrel{8}{ }$ Clasped Hands stands out among nineteenth-century sculptures, because it numbers among the few life casts conceived as finished works of art, rather than preparatory studies or personal mementos. Within this small category, even fewer present the body parts of two individuals in a single sculptural form. Moreover, most nineteenth-century sculptural casting was performed by studio and foundry employees whose names have long been forgotten; in contrast, Clasped Hands carries a celebrated byline. Born in Massachusetts in 1830, Hosmer was a prominent member of a transatlantic cultural community of artists and writers centered in Rome, including the Brownings.

9 Clasped Hands occupies a singular position in her oeuvre: she produced the cast at the outset of her artistic career and, like many Anglo-American and British sculptors working in Italy, went on to work primarily in marble and carve large-scale neoclassical figures, many on public commission. ${ }^{10}$ Two versions of Clasped Hands are the only extant plaster sculptures by Hosmer, and only two other bronze sculptures by her survive. No other life or death casts created by Hosmer have been identified. $\underline{11}$

Despite its uniqueness, Clasped Hands has largely escaped scholars' attention, and in several institutional collections, it remains in storage or displayed as a work of ephemera. Where it has been addressed, observers have dwelled upon its tender evocation of the Brownings' famous romance. 
Nathaniel Hawthorne inaugurated this tradition in his 1860 romance The Marble Faun: upon seeing a carved marble sculpture of a hand, one character remarks, "It is as good in its way ... as Harriet Hosmer's clasped hands of Browning and his wife, symbolizing the individuality and heroic union of two high, poetic lives!" $\underline{12}$ More recently, scholars have invoked a similar symbolism. Melissa Dabakis, for example, has described Clasped Hands as a "sentimental sculpture" that "serves as a testament to the famous love between the two poets". 13 Nicholas Penny has discussed Clasped Hands as "the inimitable impress of the mortal flesh of these immortal poets, eternally united". 14 Introducing a critical perspective, Marcia Pointon concludes an article about death casts with a brief consideration of Clasped Hands, basing her analysis on a bronze version. She places it in dialogue with the Brownings' writings and many other body casts in an effort to describe "some of the creative anachronisms inspired by these difficult-tocategorize, and yet fascinating, things". 15 Although she gestures to the "extensive process and agency" of cast sculpture that this article will take up, she does not attend to the distinct materialities of plaster and bronze, nor does she probe the particularities of casting living, rather than deceased, bodies. 16

This article looks anew at Clasped Hands and nineteenth-century life casting by first examining the materials and processes involved in the sculpture's making before turning to the specific individuals and bodies it represents. Accounts of cast sculpture that focus on indexicality typically discredit material and artistic agencies in favor of foregrounding the persistent presence of the original body within the resulting cast; departing from this precedent, this article initially neglects the specific human hands that, in 1853, came into contact with the first plaster mold. The first two sections examine the plaster and bronze casts alongside nineteenth-century sculpture manuals and instructional texts, many of which have not previously been studied, to understand the entanglement of material and human actors involved in the casts' making. The third and fourth sections take up the embodied experience of life casting for both sitters and artists. Ultimately, this article argues that the Brownings' hands endure not within but near Hosmer's casts, mediated by the interactions among plaster, bronze, and bodies.

\section{Plaster}

All ten versions of Clasped Hands feature two right hands holding each other. The smaller hand, bony, with pronounced veins and knuckles, nestles within the larger-large enough that the thumb and three fingers curl around the smaller. The larger hand has pronounced veins, too, particularly one along the back of the hand. All ten fingernails are neatly trimmed, neither long nor 
short. Neither hand bears any jewelry or rings. Both hands end abruptly as if their forearms were sliced cleanly just above the cuffs of their sleeves. The sleeve cuff of the smaller hand is scalloped, while the sleeve cuff of the larger hand is smooth and split on the inner wrist, suggesting a button closure out of view.

The 1853 cast is rendered here in three dimensions, and readers of this digital article can manipulate it just as in-person viewers can rotate, flip, lift, and scrutinize the physical object (Fig. 3 ). When it rests on a flat surface, Clasped Hands lies steadily with the larger hand below, its palm and wrist facing up. Inverting the position results in one or both wrists hovering above the surface. Dull white in color, with yellow and brown undertones, the cast shows signs of aging, and some original marks are obscured by later damage. In other places, intricate details are clearly visible, including on the knuckles and nails of the smaller hand, which display precisely demarcated cuticles. Hatch marks scatter across the surface of both hands, alongside wrinkles, hairs, and pores. The flat portions on each of the wrists-the only surfaces not captured by the life casting process-feature tangled markings. On the wrist of the larger hand, the name "Robert" is legible amid indecipherable inscriptions (Fig. 4). On each end, a thin wire protrudes in a loop.

View this illustration online

\section{Figure 3.}

3D model of Harriet Goodhue Hosmer, Clasped hands of Elizabeth Barrett Browning and Robert Browning, 1853. Scanned from plaster cast in the collection of the Schlesinger Library on the History of Women in America, Radcliffe Institute for Advanced Study, Papers of Harriet Goodhue Hosmer, 1834-1959, A-162, card file box. Digital image courtesy of Digital model produced by Jeremy Guillette, courtesy of the Schlesinger Library on the History of Women in America, Radcliffe Institute for Advanced Study, Harvard University, 2019. 


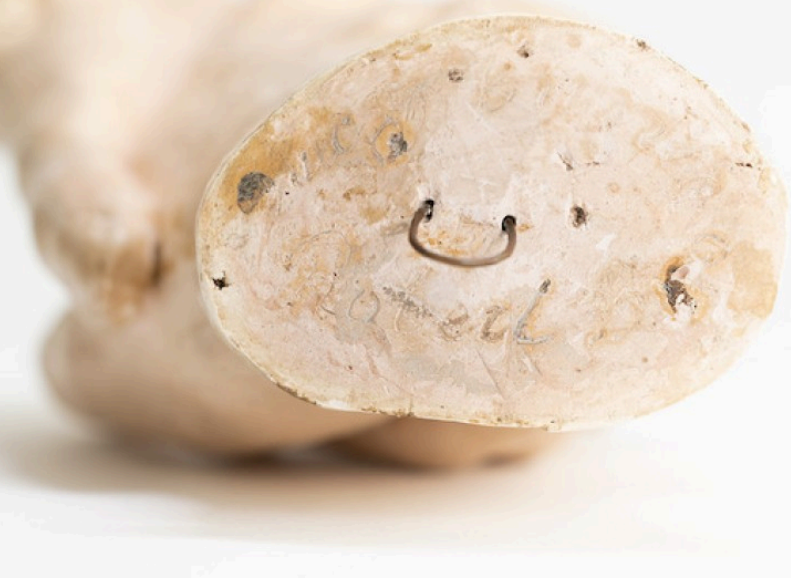

\section{Figure 4.}

Harriet Hosmer, Clasped Hands of Robert and Elizabeth Barrett Browning (inscription "Robert"), 1853, plaster, $8.3 \times 21 \times 10.8 \mathrm{~cm}$. Collection of the Schlesinger Library on the History of Women in America, Radcliffe Institute for Advanced Study, Harvard University, Cambridge, MA. Digital image courtesy of Harvard University | Photo: Kevin Grady.

Harriet Hosmer cast this first version of Clasped Hands in plaster. In the United States and Europe during the nineteenth century, sculptors purchased dehydrated gypsum as powder then mixed it with water just before use, aiming for "the consistency of cream", as one 1838 article advised, or, according to a later guide, a viscosity "like thick milk". 17 Édouard Joseph Dantan's 1887 painting Casting from Life demonstrates this preparation: a bag of dehydrated gypsum sits on one side, a bucket of water sits on the other, and within the artists' reach are two bowls of wet plaster (Fig. 5). As an 1895 article asserted, "Everything depends upon quickness and upon the thorough mixture of the plaster. Plenty of it should be in readiness, and it should be mixed as thick as the water will hold". 18 In the course of the chemical recombination of gypsum and water, the material sets, first warming and then cooling in the process. Upon setting, the plaster becomes hard and, unless exposed to extreme conditions, does not shrink or crack, though it remains vulnerable to abrasions and surface damage. An 1885 article warned that plaster is "easily disfigured, harboring with greedy hospitality every particle of dust". $\underline{19}$ 


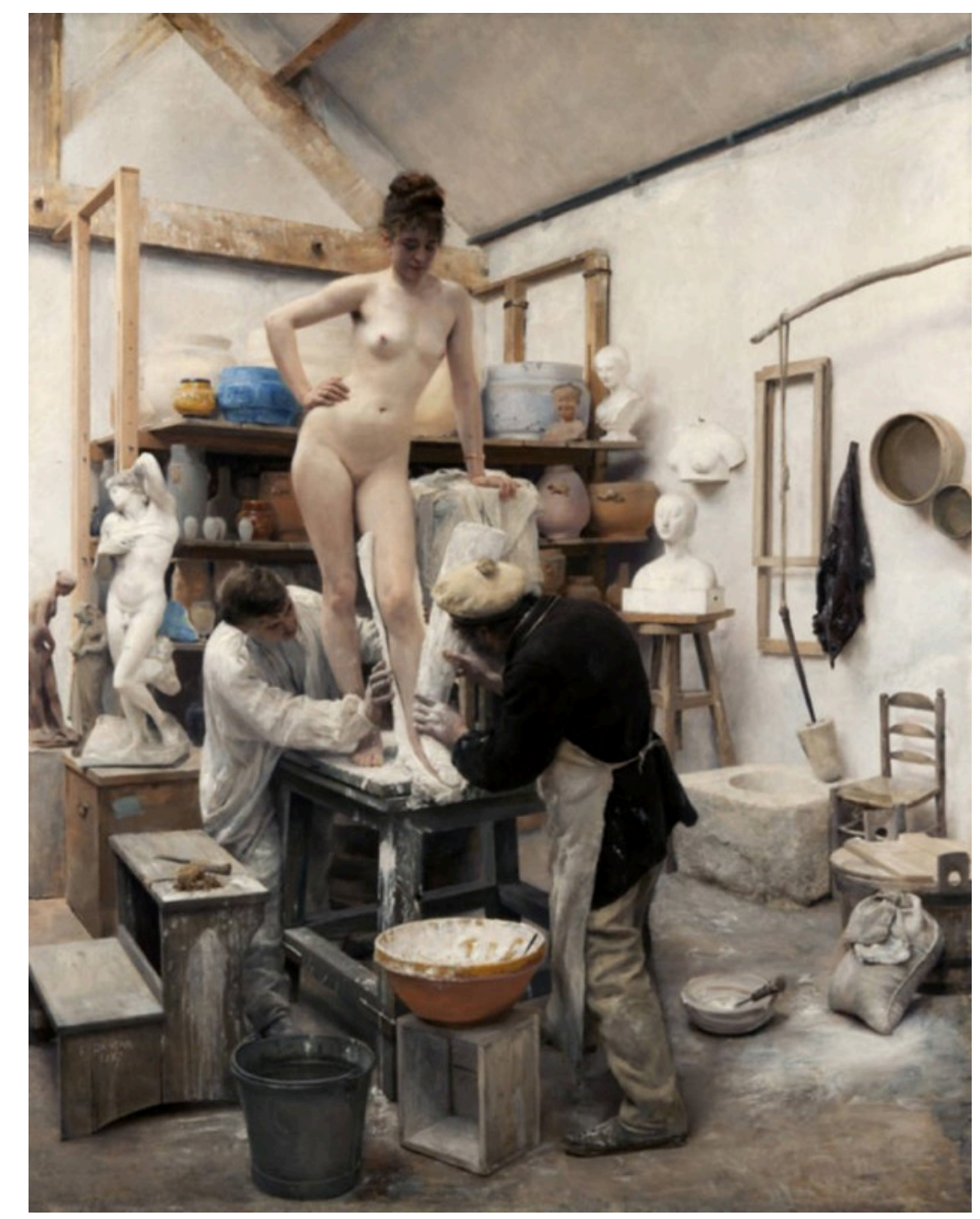

\section{Figure 5.}

Édouard Joseph Dantan, Casting from Life, 1887, oil on canvas, $165.1 \times 131.5 \mathrm{~cm}$. Collection of the Gothenburg Museum of Art, Gothenberg, Sweden (F 21). Digital image courtesy of Gothenburg Museum of Art.

Hosmer claimed that her familiarity with plaster enabled her to produce Clasped Hands-at least the first version-herself, as opposed to relying on studio staff. She seems to have experimented with plaster casting, including of hands, in her youth: an 1868 biographical sketch traced her "passion for sculpture" to her late teens, when she made "plaster casts of the hands of her mates". $\underline{20}$ Once she had established her practice, her studio, like those of her fellow sculptors, certainly abounded in plaster, wielded by Hosmer and her employees for various purposes associated with the preparation of marble figures. ${ }^{21}$ In an 1896 speech Hosmer delivered in Chicago, she emphasized her involvement in the cast's making. Recalling her first winter in Rome, she said, 
I then conceived the idea of casting their hands and asked Mrs. Browning if she would consent. "Yes" she said "provided you will cast them yourself but I will not sit for the Formatore". Consequently I did the casting myself and therefore can guarantee their genuineness. $\underline{22}$

Neither this speech nor any other source documents the particular method she employed to create the intricate form of Clasped Hands. It would have posed myriad challenges to even a skillful caster: many undercuts, narrow shapes, the necessity of removing two hands from the mold, and, above all, the need to accommodate the comfort of both sitters.

In the absence of explicit documentation about the process of casting Clasped Hands, instructions published in the nineteenth century and examples of life casts by Hosmer's peers record the process that she must have undertaken. Contrary to claims of contingency in accounts of indexical portraiture, the complexity of the historical life casting process-from making a mold of living bodies to producing a plaster cast from that mold-speaks to both material and artistic agency in determining the resulting sculpture. Historical sources reveal how human hands and artistic materials came together in tension, constraining, resisting, and threatening one another. Indicative of broader assumptions about body casts, Nicholas Penny has suggested that the "documentary value" of Clasped Hands would have been "diminished by the assertion of artistic mediation". $\underline{23}$ In contrast, these understudied texts suggest a historical conception of life casting distinct from later interpretations, one which recognized an artist's skill and choices without diminishing the significance of the resulting sculpture.

Before Hosmer applied plaster to the Brownings' bodies, she must have prepared their skin for prolonged contact with the setting mold. Like the first cast, the original mold was almost certainly produced in plaster, the only material available to Hosmer that would not harm the Brownings' hands. Nineteenth-century sculpture manuals prescribed various materials that could protect skin and hair from painful exposure to hardening plaster without depriving the resulting mold of detail. One author suggested "a slight coating of salad oil", and later accounts encouraged the use of "vaseline or lard", if oil did not prove substantial enough, or "butter or oleomargarine" for

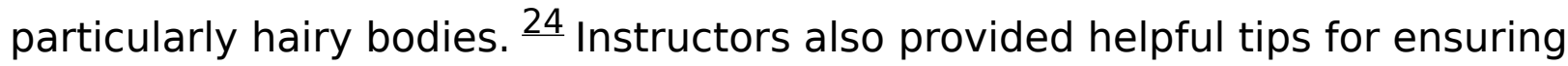
proper preparation, such as: "Hold the hand between the eye and the light and if hair can be seen it must be made to lie flat upon the skin, as it would otherwise be pulled out when the mold is removed-a sensation which is said to be unpleasant". $\underline{25}$ Another unpleasant sensation threatened if a sculptor applied too much plaster. Manuals suggested aiming for a thickness between 
$1 / 8$ and $1 / 4$ inch, or else, as one writer warned, "the fingers in the cast are very likely to be broken by the weight of the plaster forming the mold". This author further cautioned against pouring plaster onto the human body, opting instead for layering it gently with a spoon. $\underline{26}$ On a smaller scale, these warnings recall a more well-known incident, in which British artist Benjamin Robert Haydon nearly suffocated a man to death in an attempt to create a cast of his torso in 1810. 27

Indeed, Hosmer numbered among many artists who produced life casts, often as studies for sculpture in marble, bronze, or other durable materials. As with other sculptural processes, plaster casting, both of human bodies and other sculptures, might have been undertaken by well-known sculptors themselves or by the assistants they employed in their workshops. While relatively few nineteenth-century plaster life casts have endured, even fewer nineteenth-century plaster molds survive. Sculptors intentionally destroyed many plaster molds, known as waste molds, in the process of producing casts, and many others were surely discarded over time. A few extent examples, roughly contemporary to Clasped Hands, hail from the studio of Hiram Powers, including this mold of a child's hand (Fig. 6). It demonstrates that Powers and his workshop created piece molds, or molds divided into sections to accommodate undercuts and complex forms. Technical analysis has revealed that Powers' studio crafted an eight-piece mold to cast this single, splayed hand. $\underline{28}$ Hosmer, too, must have created a multiple-piece mold to capture the Brownings' intertwined hands. 29 


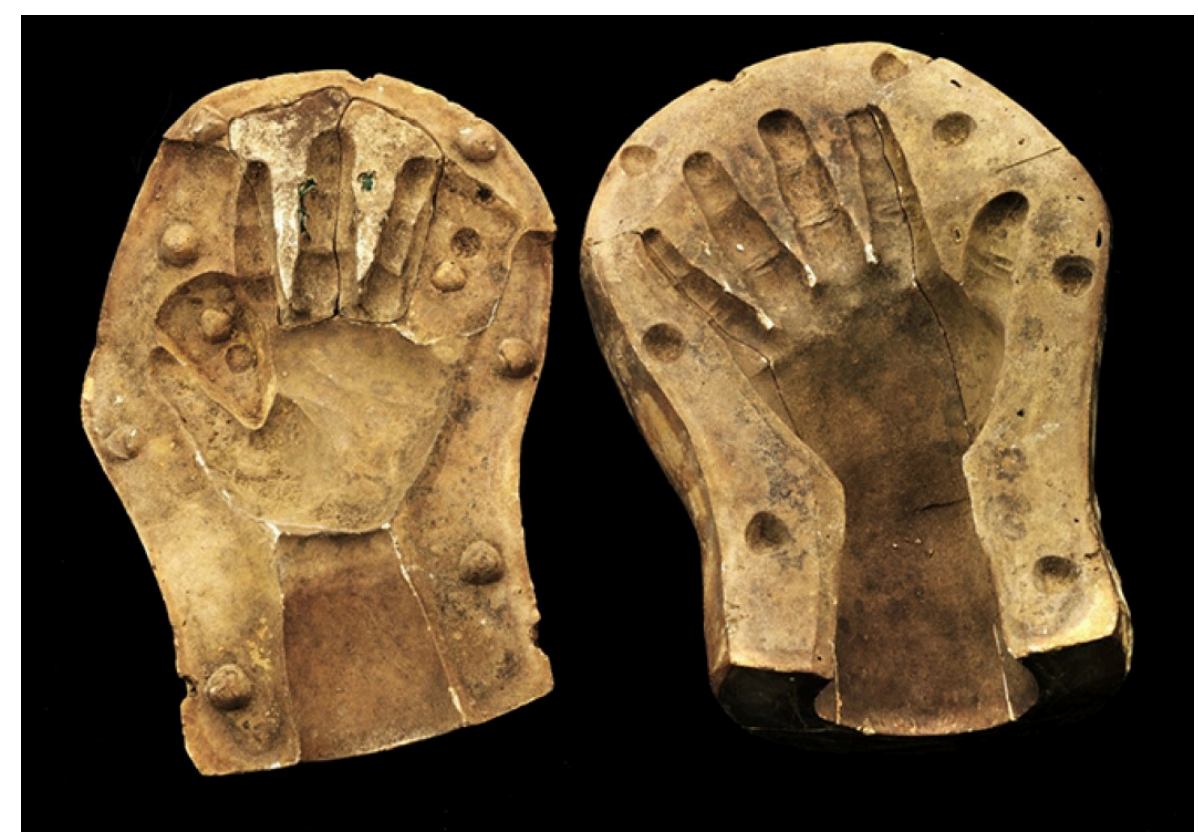

\section{Figure 6.}

Studio of Hiram Powers, Mold of a Child's Hand, 1840-1850, plaster. Collection of the Smithsonian American Art Museum, Washington, DC (1968.155.173A-F). Digital image courtesy of Smithsonian American Art Museum, Washington, DC.

Making a piece mold constituted a critical step in Hosmer's process and epitomizes how her choices and the materiality of plaster influenced the resulting cast. As an 1838 article explained, creating a piece mold required "great tact and judgment" on the part of the sculptor, "since attention must be paid to all the depressions and hollows of the figure, and the divisions cut in such directions as to facilitate the removal of the pieces". ${ }^{30}$ An 1895 article intended for amateurs advised the use of a "waxed silk thread" for cutting the pieces, but qualified that "since the shell cannot be made very thick, breakages frequently occur, and much skill is necessary in putting together the pieces of the mould in order to get a cast from them". 31 Specifically with regard to plaster casts of hands, one manual noted how the position of hands and fingers would determine the number of pieces: "If the hand is partly closed, or is holding something, two or more threads may be necessary to so divide the mould that the hand can be taken out". $\underline{32}$ Often, plaster casts display evidence of their molds, in the form of raised lines at the places where the pieces of the mold intersected. Despite its poor condition, the 1853 cast features a faint trace of a piece mold process along the larger pinky down to the wrist. According to one 1885 writer, "the raised lines, which always show the union of the different pieces of a mold, are never removed for fear of injury to the surface, but are kept as fine as possible, so that, in most cases, only close inspection will reveal the gossamer-like threads". 33 This passage indicates how artistic intervention 
might actually enhance the reference of a cast sculpture to the represented object, rather than diminish it. The raised lines that remain evince the casting process and the artist's choices, indirectly revealing the object's former presence.

Once the plaster mold had been successfully removed from the Brownings' hands, Hosmer produced the first plaster cast. As she did with the Brownings' hands at the outset of the casting process, she had to coat the surface of the mold with a viscous barrier, probably shellac, to prevent the mold and the cast from adhering to each other. The mold was likely tinted with "bluing or other color" so that the mold and the cast, both made of plaster, "could be easily distinguished". 34 Due to the fragility of plaster, artists often hurried to produce the first cast and thus maintain "the delicate texture of the skin" captured by the casting process. 35 Many nineteenthcentury manuals emphasized the importance of the texture of life casts. For one author, "the fine outlines and characteristic surfaces" constituted "the very soul of the work of art". $\underline{36}$ Another insisted that "the special beauty of a cast from life is in its natural surface". 37

Despite such emphasis on the plaster surface, the cast could have been marked or refined after removal from the multiple-piece mold and before the plaster set completely. Hosmer may have chosen to obscure traces of the piece-mold process by smoothing the places where the pieces intersected, as discussed above. At this stage, too, the text on each of the wrists was probably added. Although now difficult to read, these inscriptions seem to have featured the sitters' names on their corresponding wrists. In 1891, a visitor to Hosmer's studio remarked, "One of the interesting things in Miss Hosmer's studio is a plaster cast of the clasped hands of Robert and Elizabeth Barrett Browning. Upon the wrists at either end are the autographs of the poets, with the date". $\underline{38}$ The use of the term "autograph"-reiterated in subsequent publications of the 1890s-raises the enticing possibility that the Brownings' names were manually inscribed by the poets themselves, their hands reflexively marking their own representation and attesting to the authenticity of the likeness. $\frac{39}{}$ Whether the inscriptions were added by Hosmer or the Brownings, and whether or not they displayed signatures indicative of unique handwriting, the wrists interrupted the accurate and precisely rendered surface, and offered an opportunity to enhance and describe the sculpture.

When the first cast hardened completely, it could then serve as a model for additional versions, especially if the original mold was destroyed in the first casting process. Making new molds from the first cast might account for the metal wires protruding from the Brownings' wrists, as they would support the easy maneuvering of the object during further casting processes. No longer 
obliged to cater to the comfort of her sitters, Hosmer could employ other mold-making and casting techniques, as she would go on to do in producing bronze versions. For the later plaster version, however, the piece-mold process was likely repeated, evident in the raised lines contouring the surface (Fig. 7).

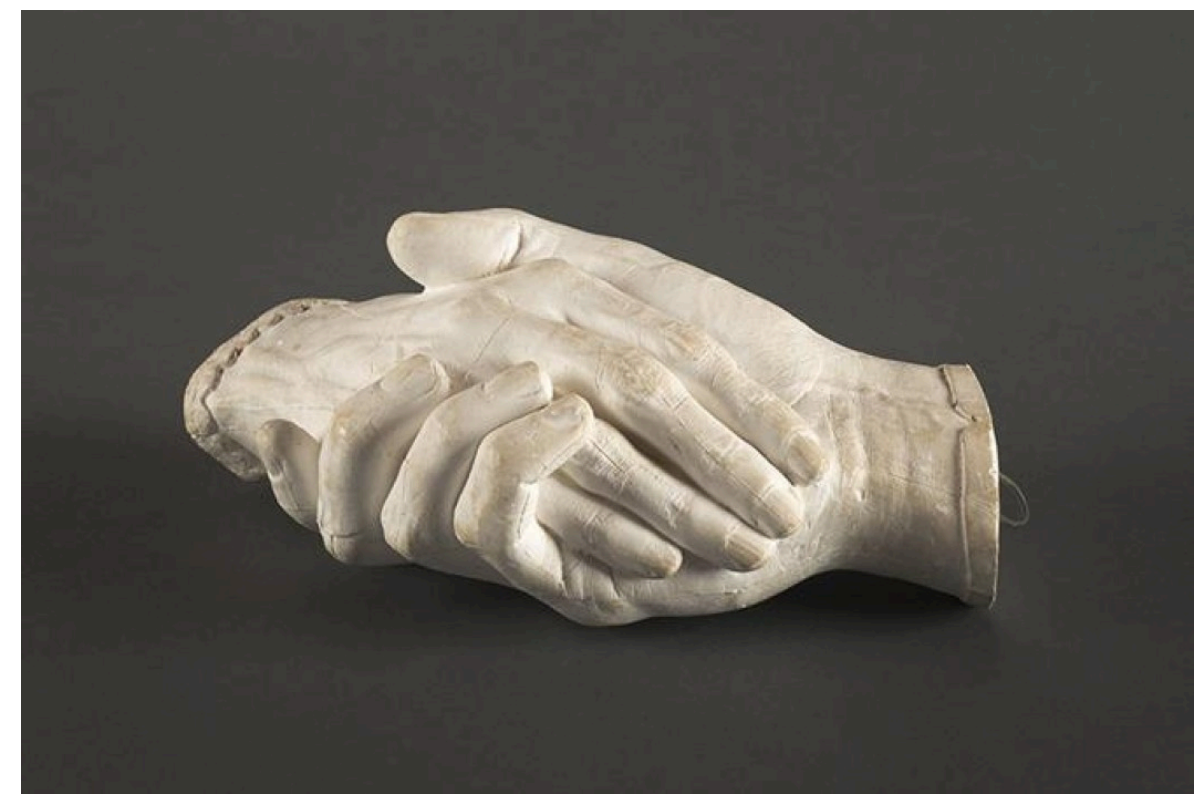

Figure 7.

Harriet Hosmer, Clasped Hands of Robert and Elizabeth Barrett Browning, 1853, plaster, $8.25 \times 20.95 \times 11.43 \mathrm{~cm}$. Collection of National Museum of Women in the Arts, gift of Molly F. Sheppard. Digital image courtesy of National Museum of Women in the Arts.

Viewing the plaster versions of Clasped Hands in dialogue with historical documentation of life casting processes uncovers a set of complex negotiations, from oily barriers between skin and plaster, and between plaster and plaster, to the susceptibility of plaster to dust and abrasions. At every step, individuals and materials acted upon one another and collectively mediated the relationship of the cast to the original object. These interactions define Clasped Hands: they attest not to the continued presence of the Brownings' hands within the sculpture, but to their carefully cultivated nearness to it. Similarly confirming the multiple agencies at play, the nineteenth-century manuals and instructions quoted above do not place in opposition the intervention of an artist and a cast's claim to accurate representation. In fact, the artist's skillful actions, from the speed with which she moved to the way in which she cut the mold, determined the success of the resulting object. Affirming the compatibility of an artist's actions and a cast's accuracy, one author praised plaster casting because "the mold from which the cast is formed being taken directly on the original itself, every 
beauty or defect must be reflected exactly". In the same paragraph, she stated, "Great importance is well attached to the faultlessness of the execution of all these casts". $\underline{40}$

\section{Bronze}

In her 1896 speech about Clasped Hands, Hosmer noted that she was hesitant to produce bronze casts until compelled to do so by a friend: "I have more often than once been asked to have these Hands cast in more durable substance than plaster and I have invariably refused-but I could not say nay to a certain dear friend of mine to whom I owe so much." $\underline{41}$ Hosmer did not specify the rationale behind her refusal in this speech, but in an 1858 letter, she described bronze as "at best but a cold and harsh material", which may account for her reluctance to use it to render human hands. ${ }^{42}$ Robert Browning seems to have agreed with her: mulling over other sculptures he saw in Italy, he wrote to Hosmer in 1854, the year after she cast his hand in plaster, that "bronze is such inadequate stuff for the expression of flesh". 43

When Hosmer finally agreed to comply with her unnamed friend's wishes, she produced several bronze versions of Clasped Hands (Figs. 8-10), likely with the intention of selling them to eager patrons. Although more durable, the bronze versions are heavier and shinier than those in plaster, and the darker color and sheen of the surface prevents viewers from seeing the intricate details of pores, hairs, and wrinkles. Furthermore, the pale tone of plaster more closely matches the white skin of the Brownings, whereas the eight bronze versions feature varying patinas, ranging from deep brown with hints of blue and green to nearly gold. $\stackrel{44}{ }$ They all read, on Robert Browning's wrist, "Hands of Robert and Elizabeth Barrett Browning, cast by Harriet Hosmer, Rome 1853", and on Elizabeth Barrett Browning's wrist, "Copyright" (Figs. 11-12). On all versions, the words correspond to the same unusual and distinctive pattern, but they exhibit minute discrepancies in their layout, suggesting that the inscriptions were added to each cast individually. The text thus illustrates the challenge of creating exact copies, just as it affirms the desire to do so. Together with the material qualities of the bronze surfaces, these inconsistencies distance the bronze sculptures from the hands they represent. 


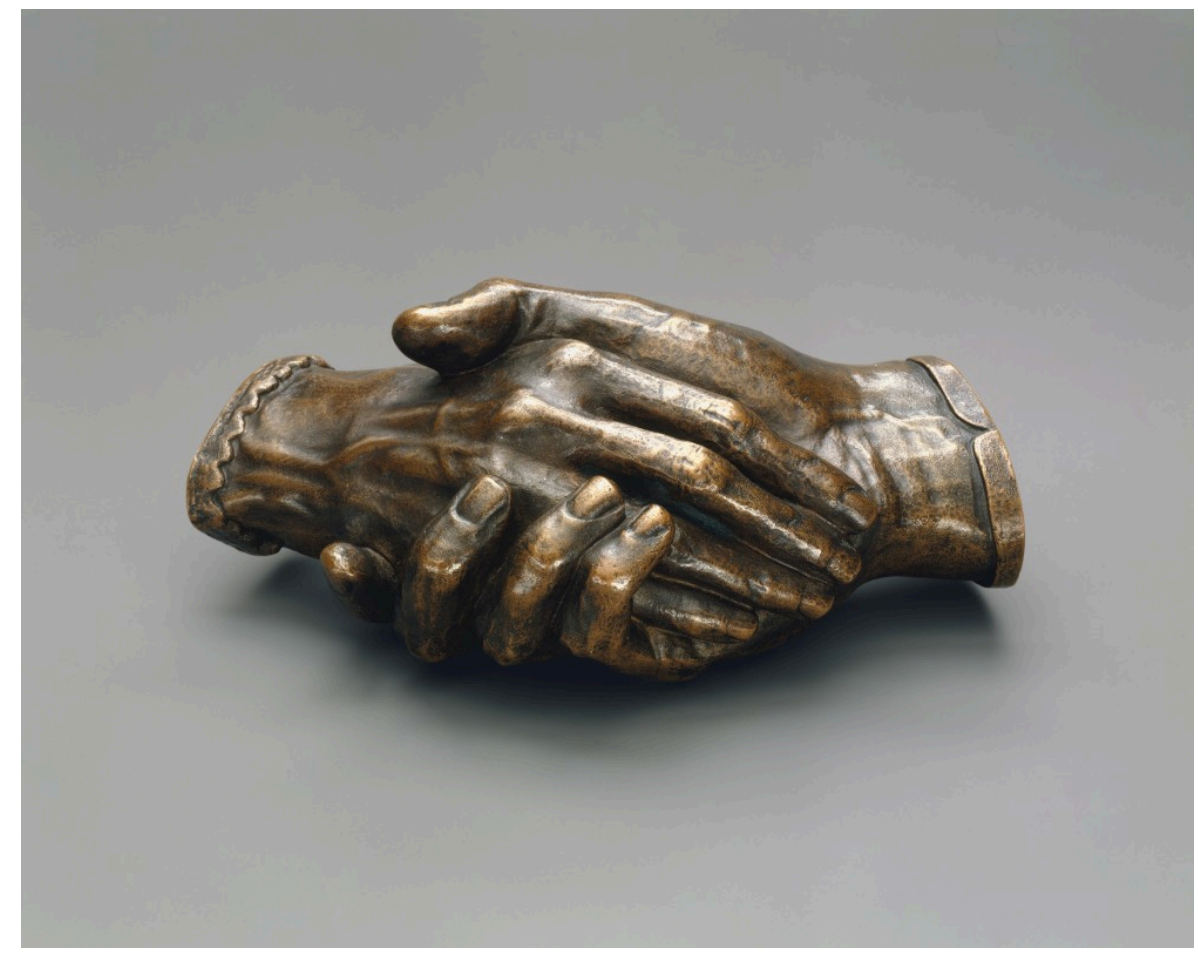

Figure 8.

Harriet Hosmer, Clasped Hands of Robert and Elizabeth Barrett Browning, cast after 1853, bronze, $8.3 \times 21 \times 10.8 \mathrm{~cm}$. Collection of The Metropolitan Museum of Art, New York (1986.52). Digital image courtesy of The Metropolitan Museum of Art. 


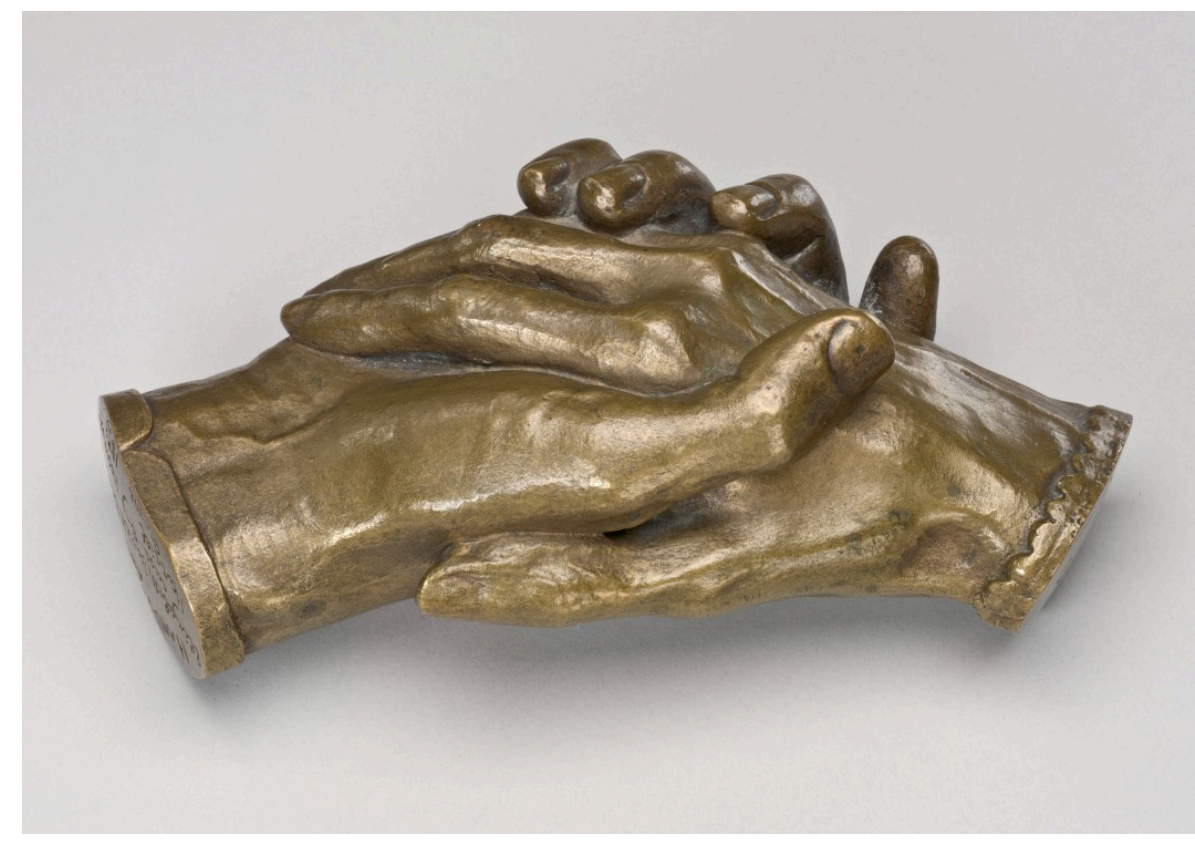

\section{Figure 9.}

Harriet Hosmer, Clasped Hands of Robert and Elizabeth Barrett Browning, cast after 1853 , bronze, $8.3 \times 21 \times 10.8 \mathrm{~cm}$. Collection of the National Gallery of Art, Washington, DC (2005.41.1). Digital image courtesy of National Gallery of Art.

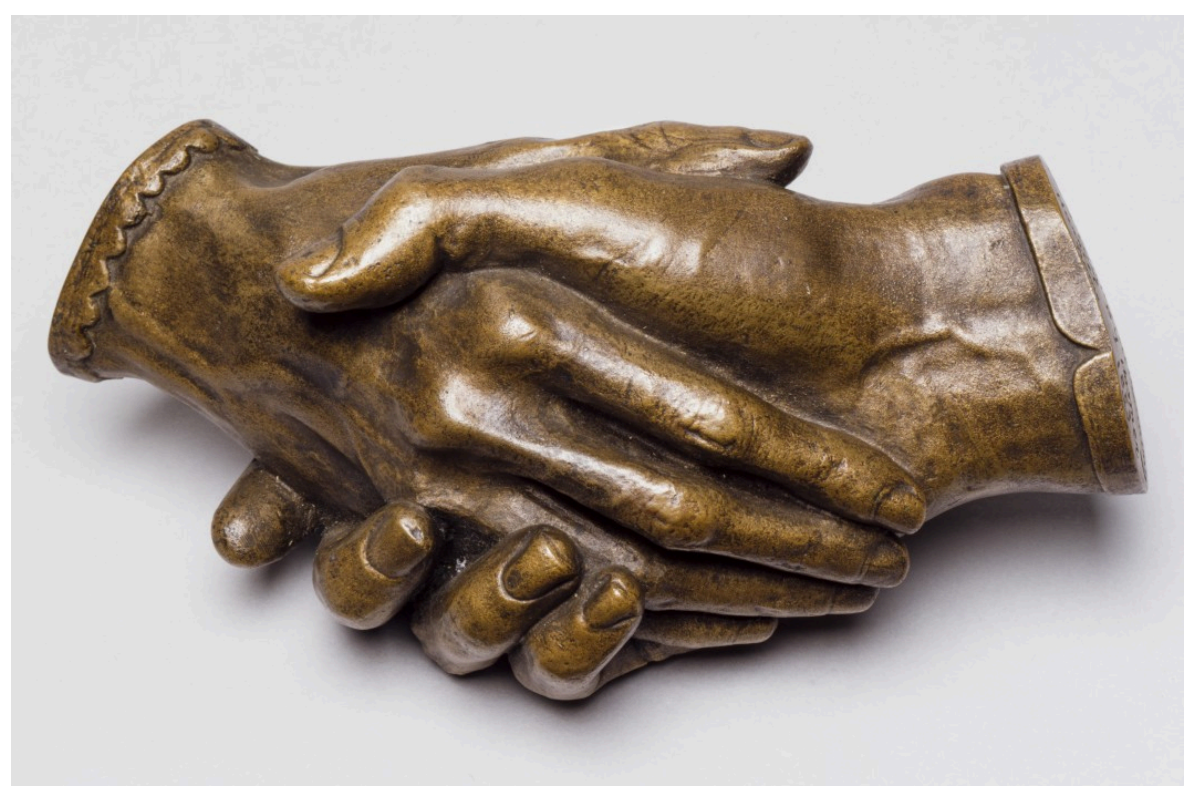

\section{Figure 10.}

Harriet Hosmer, Elizabeth Barrett Browning; Robert Browning, cast after 1853, bronze, $21 \mathrm{~cm}$ long. Collection of the National Portrait Gallery, London (NPG 3165). Digital image courtesy of National Portrait Gallery. 


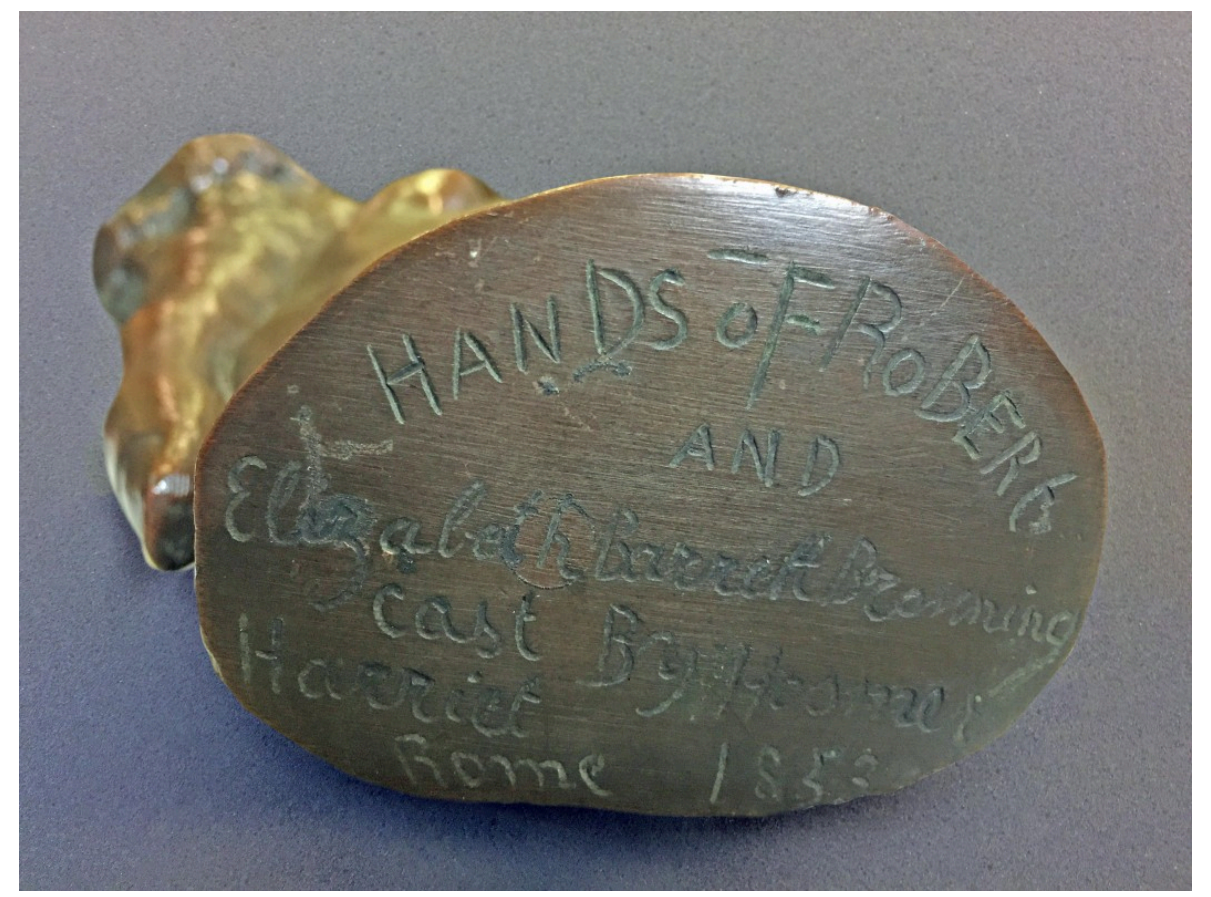

Figure 11.

Harriet Hosmer, Elizabeth Barrett Browning; Robert Browning (inscription "Hands of Robert / and / Elizabeth Barrett Browning / cast by / Harriet Hosmer / Rome 1853"), cast after 1853, bronze, 19.6 × 45 x $17.7 \mathrm{~cm}$. Collection of the Newark Musuem of Art (76.8). Digital image courtesy of Katherine Fein. 


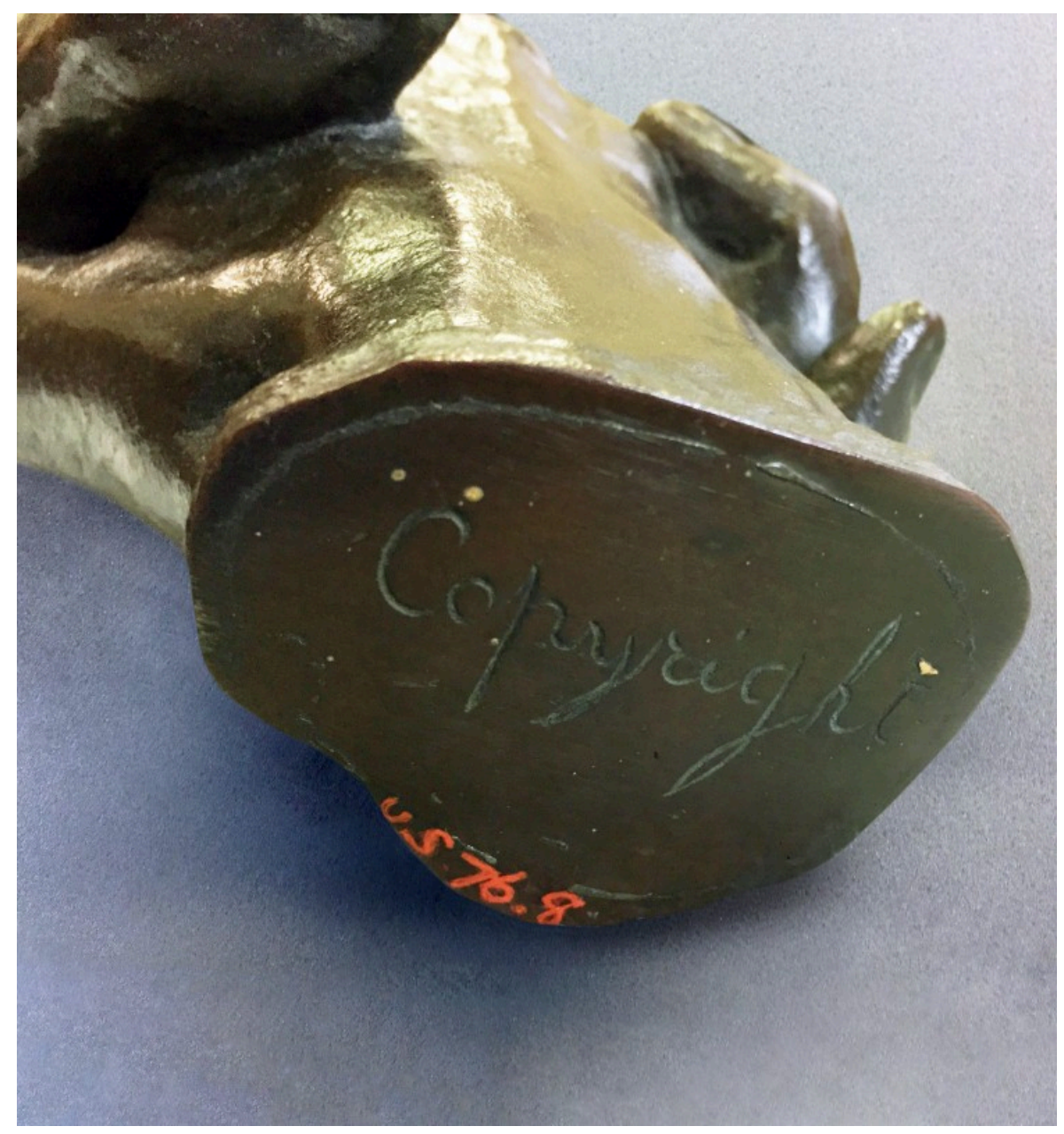

\section{Figure 12.}

Harriet Hosmer, Elizabeth Barrett Browning; Robert Browning (inscription "Copyright"), cast after 1853, bronze, 19.6 x $45 \times 17.7 \mathrm{~cm}$. Collection of the Newark Musuem of Art (76.8). Digital image courtesy of Katherine Fein.

Like plaster, bronze contributed to and constrained the making of Clasped Hands. Bronze is a metal alloy, typically composed of copper and tin. Similar to other alloys in comparison to pure metals, bronze is harder and stronger than copper and has a lower melting point, features which enable casting and shaping. Altering the tin content yields bronze with different qualities (such as sonorousness for bells), and bronze used for sculpture usually has a low tin content. Small quantities of lead and zinc were commonly added to bronze in the nineteenth century prior to casting, to smooth the melted substance. $\frac{45}{}$ Although less porous and fragile than those of plaster, bronze surfaces similarly manifest their interactions with the environment. After shaping, nineteenth-century sculptors altered the color and sheen of bronze through chemical processes, and new discoveries during this era brought patination increasingly under human control. $\stackrel{46}{ }$ For small-scale work, sculptors could submerge bronze objects in chemical baths or apply 
chemicals with brushes. $\frac{47}{}$ Manual labor itself also impacted patina, as oil and sweat produced by sculptors' hands came into contact with bronze surfaces.

Due to the surge in production of bronze sculpture in the nineteenth century, historical methods of bronze casting are well documented in archival sources. $\frac{48}{}$ Moreover, few artists maintained the equipment needed to create bronze sculpture in their studios; instead, they commissioned foundries to cast their plaster, marble, or clay sculptures or models into bronze. Bronze foundries were first established in the United States during this era, although some sculptors remained loyal to European, primarily German and Italian,

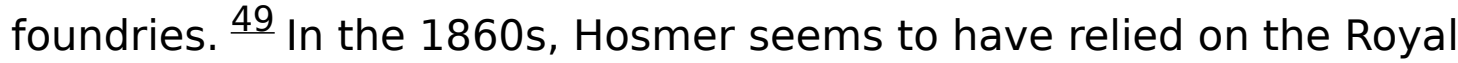
Foundry in Munich to cast her monument to Thomas Hart Benton, but due to the expense and her limited travel later in life, Hosmer likely turned to a foundry in the United States to cast Clasped Hands in bronze. ${ }^{50}$ Before the final years of the nineteenth century, bronze foundries in the United States primarily used sand casting, especially for small-scale sculpture. This method resembled plaster casting, but instead of applying wet plaster to a model, sculptors immersed a model in a tray of wet sand. Upon removing the cast from the hardened sand mold, sculptors typically refined the surface, using carving tools and applying chemical solutions and polishes. $\underline{51}$

Nineteenth-century writers lamented the lack of public knowledge about the process of bronze casting. In 1895, despite the ubiquity of bronze sculptures, one author wrote, "Few have any idea of the difficulty of casting a large bronze statue. The popular idea is that molten bronze is poured into a mold and then when the metal has cooled, the mold is knocked off and the statue is complete". 52 Even with regard to small bronzes, which occupied both public and private spaces, observers and collectors may have remained ignorant of specific techniques and materials. A London newspaper noted, "Most persons in easy circumstances are owners of certain small bronze figures. ... Few persons, however, have any but the vaguest ideas as to the processes by which these are made. They would probably tell you that they were cast, but that would be the extent of their information". $\underline{53}$ In bemoaning public ignorance about the casting process, these authors highlight its complexity and the necessity of artistic skill.

Such texts also reflect the lower status afforded to the people who usually performed sculptural casting. With plaster, and to an even greater extent with bronze, most casting in the nineteenth century would have been executed by individuals with sophisticated skills but who did not often participate in the conception and design of sculpture. In Britain and the United States, many men employed in sculpture studios and foundries were Italian immigrants, and Hosmer, like her fellow sculptors, employed Italian 
assistants in her studio in Rome. $\frac{54}{}$ Among British and Anglo-American art patrons, the social invisibility of these men, known as formatori, contributed to the perception of casting as a mechanical, rather than artistic, process; reciprocally, belatedly acknowledging the degree of artistry recuperates their creative labor. A few nineteenth-century articles complicated the distinction between sculptor and assistant by condemning artists who did not themselves have experience in casting. Recognizing the complexity of the casting process and the many choices made by the individuals involved, one critic writing in 1885 regretted that "in the various art educational establishments in this country, the student of sculpture is merely taught drawing and modeling, but is unable to learn the other processes whereby alone his modeled work can be rendered permanent". For him, casts made by other hands could not be deemed original works of art:

Unless these are really produced by the artist himself, and bear the palpable impress of his own mind and hand, unimpaired by foreign touch, and perfect throughout in character and individuality, I am really unable to see what value they can possess beyond that of a skillfully executed copy. 55

Even as this and other historical texts reveal tension around the perception of artistic agency in the casting process because of social status, they insist on the importance of an artist's skill and choices in determining the final form of the sculpture.

As a woman supervising a workshop of men, Hosmer had to defend herself against doubts of her authorship and reiterated the importance of her oversight of all aspects of sculptural production. She faced allegations that her mentor, British sculptor John Gibson, deserved credit for sculptures she claimed as her own, and that she relied too heavily on the Italian men who staffed her studio. ${ }^{56}$ In response, she wrote an article titled "The Process of Sculpture" to "raise the veil upon the mysteries of the studio", in which she asserted her role as an artist, outlining in detail the process of creating marble sculpture and specifying which tasks were performed by the sculptor and which by the assistants. $\frac{57}{}$ While insisting upon hierarchy in a studio, she gestured toward praising the skill of casters and carvers, acknowledging that "much depends upon the workmen to whom this operation is intrusted [sic]". 58 She also assured readers that the division of labor in her studio mirrored that of her fellow sculptors, including well-known men: "We women-artists have no objection to its being known that we employ assistants; we merely object to its being supposed that it is a system peculiar to ourselves". $\frac{59}{\mathrm{An}}$ 1861 photograph (Fig. 13) makes visible how she stood out from her male employees with a presence that belied her small stature. In her Boston Globe 
obituary, the author recalled how, in a studio full of men, Hosmer "superintended her work herself" and "wielded the chisel more adroitly than any practiced workman". $\underline{60}$

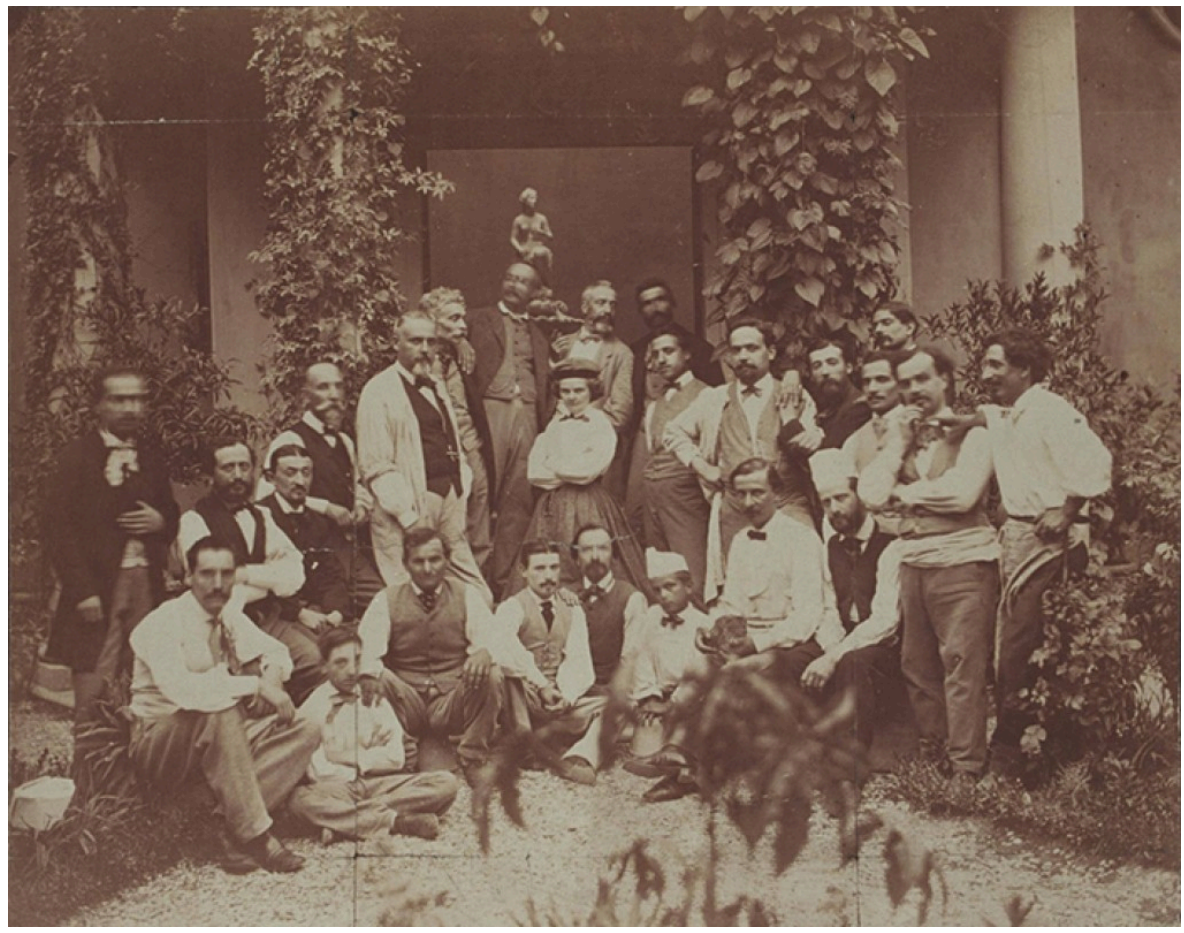

Figure 13.

Unknown photographer, Harriet Hosmer with Her Italian Workmen, 1861, albumen print, $25.4 \times 20.32 \mathrm{~cm}$. Collection of the Schlesinger Library on the History of Women in America, Radcliffe Institute for Advanced Study, Harvard University, Cambridge, MA (A162-74-1). Digital image courtesy of Harvard University.

As a woman artist, she also contended with accusations of impropriety, particularly around her use of nude models. Women artists were denied access to nude models, an essential element of men's artistic training, throughout the nineteenth century, but Hosmer defied this prohibition. In fact, Barrett Browning wrote of visiting Hosmer's studio to find her "tete a tete or rather corps a corps with a model", though Barrett Browning reflected that "an artist like Hatty is justified by her art". $\frac{61}{6}$ Less generous, sculptor Thomas Crawford bemoaned Hosmer's "want of modesty", describing how she "had casts for the entire female model made and exhibited in a shockingly indecent manner to all the young artists who called upon her". $\underline{62}$ Unfortunately, none of these life casts-presumably made of plaster-survive, reducing any further analysis to speculation. Yet like the scandal around the authenticity of her sculptures, this episode confirms 
Hosmer's hands-on approach to sculpture, just as it makes clear that, within a nineteenth-century patriarchal society, Hosmer consistently needed to perform a public identity and reaffirm her professional status. $\underline{63}$

Despite her usual commitment to defending her artistic skill, however, Hosmer insisted that in the process of casting Clasped Hands in bronze, she manipulated the result as minimally as possible-or, perhaps, that she instructed others to do so. Describing the bronze versions in her 1896 speech, Hosmer stated, "These Hands are exactly as they came from the mold as I have wished to preserve at the expense of finish all their characteristics of texture". $\frac{64}{6}$ This claim indicates Hosmer's interest in how the sculpture refers, through a series of molds and casts, back to the physical presence of the Brownings' hands, and seems to suggest that, in Hosmer's opinion, creative intervention might diminish this reference. The passivity of this statement also aligns with the notion that Hosmer did not execute the bronze casts herself, and that other hands-those of unnamed foundry assistants-also left their mark on these objects. Earlier in the speech, however, Hosmer had emphasized that Barrett Browning requested that Hosmer, specifically, execute the first plaster mold, and the inscription "Copyright" further declares Hosmer's ownership of the sculpture. $\underline{65}$ Torn between competing rationales for the sculpture's uniqueness in its different forms, Hosmer seems to have alternately overstated and understated her role in its creation. In comparison to her ambiguous descriptions of the bronze versions, her desire to associate the original plaster version with her artistry may also reflect the difference between casting sculptural objects and living bodies.

\section{Bodies}

Where typical accounts of life casts discredit artistic and material agencies in favor of foregrounding physical contingency and the presence of the living body, this essay has so far neglected the human hands that, in 1853, came into contact with the first plaster mold. Attending to the bodies of the famous sitters reveals how they too participated in the multifaceted material negotiations of the casting process. Moreover, recognizing the complexity of these bodies further troubles the assertion of the Brownings' enduring presence.

With their fingers pointing in opposite directions, the Brownings must have posed across from each other, the open space between them bridged by their intertwined right hands. As each faced their spouse, while Hosmer worked to apply plaster, and while they waited for it to dry, they had to maintain their position or else damage the mold. With regard to creating life masks, an 1899 manual instructed: "The subject must hold his features 
quietly during the operation, for even a smile would break the thin film of plaster from the face". Maintaining one's position would be uncomfortable, and this author cautioned that, "If the mask is left on too long it becomes warm and causes the perspiration to flow freely. But the subject always has the alternative of laughing until the mask lies in small pieces at his feet". $\underline{66}$

In life casts as well as photographs, the permanent fixture of an ephemeral presence comes first through the temporary fixture of the body in motion. As Harvey Young has explored through his work on daguerreotype portraits of enslaved African Americans, maintaining stillness is neither passive nor motionless. $\frac{67}{}$ The Brownings had to actively enact motionlessness-at least in their extremities-while they waited for Hosmer's wet plaster to set. As they each performed stillness, they also had to rely on the other to do the same. The presence of two hands encased together in wet plaster would only increase heat and discomfort. Of course, the human body is never truly still: blood continued to run through the Brownings' veins, their hands produced oil and sweat, and involuntary motions could not be avoided. One set of nineteenth-century casting instructions warned that "the special difficulty of the work is due to involuntary movements of the muscles trying to adjust themselves to this weight, which causes the plaster to slip", encouraging the caster to move quickly to decrease the impact of such motion. $\underline{68}$ The fleshon-flesh contact in combination with the uncontrollable and unending movement of the body thus renders motionlessness even more active, resisting the discomfort of prolonged confinement. The Brownings probably had to hold their position for between 10 and 20 minutes, depending on temperature, humidity, and the thickness of the plaster.

Those tense, sweating hands belonged to two specific individuals. In late 1853, when the 23-year-old Harriet Hosmer created Clasped Hands, Robert Browning was 41 years old, Elizabeth Barrett Browning was 47, and they were both established poets. Painted portraits (Figs. 14 and 15) demonstrate how the Brownings' public personas hinged on the perception of their bodies: on Robert Browning's vigor and, more acutely, on Elizabeth Barrett Browning's chronic infirmity. In these paintings, commissioned by a friend of the Brownings a few years after Hosmer produced Clasped Hands, Robert Browning leans forward, and Elizabeth Barrett Browning rests against an upright chair, which constrains her and emphasizes her small stature.

Beginning in her teens and persisting until her death at the age of 56, she experienced weakness and pain centered on her chest and spine. During her lifetime, doctors were unable to diagnose her illness, and she received varied treatments including leeches, prolonged bed rest, and opium. $\underline{69}$ 


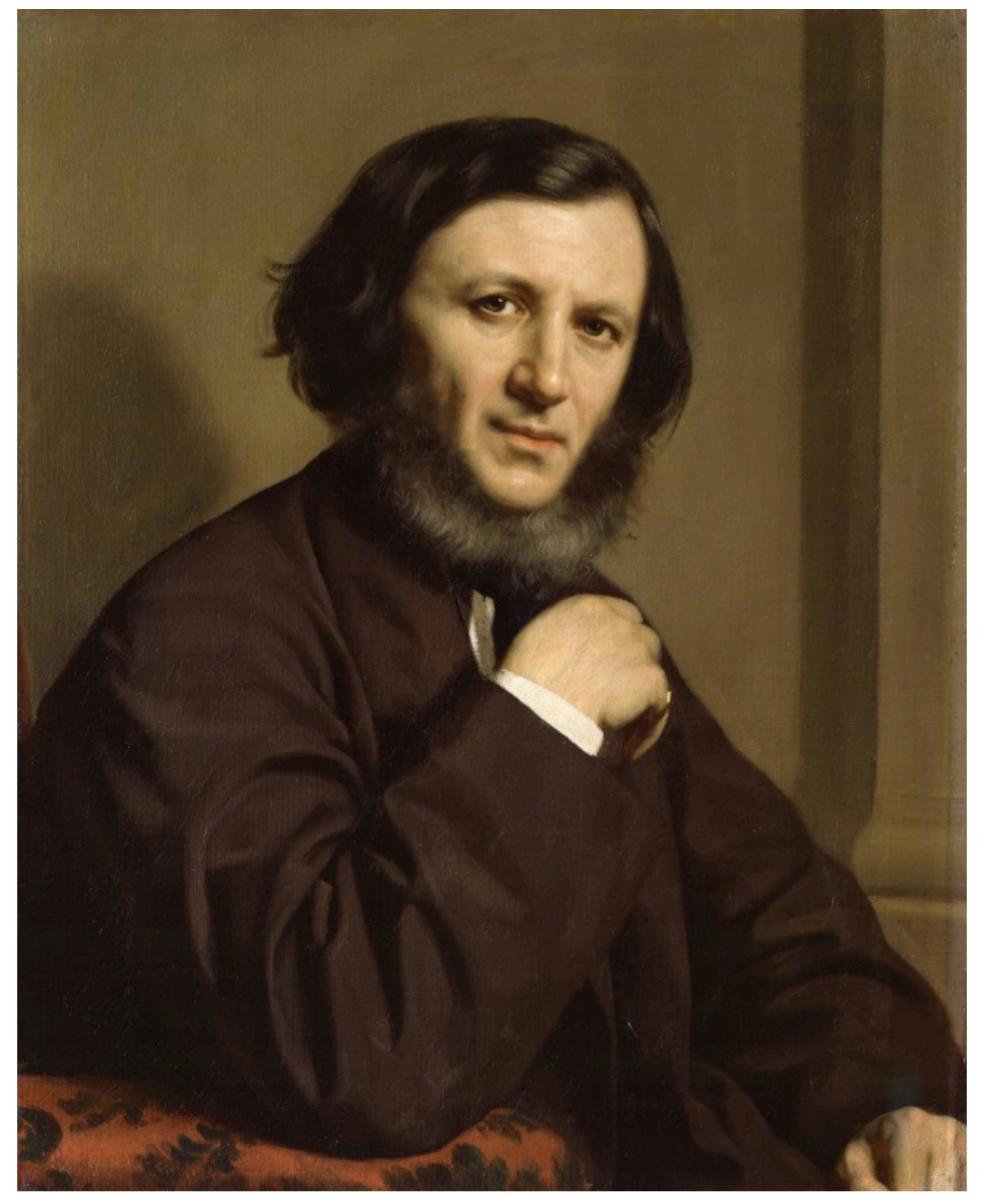

Figure 14.

Michele Gordigiani, Robert Browning, 1858, oil on canvas, $72.4 \mathrm{x}$ $58.7 \mathrm{~cm}$. Collection of the National Portrait Gallery, London (NPG 1898). Digital image courtesy of National Portrait Gallery. 


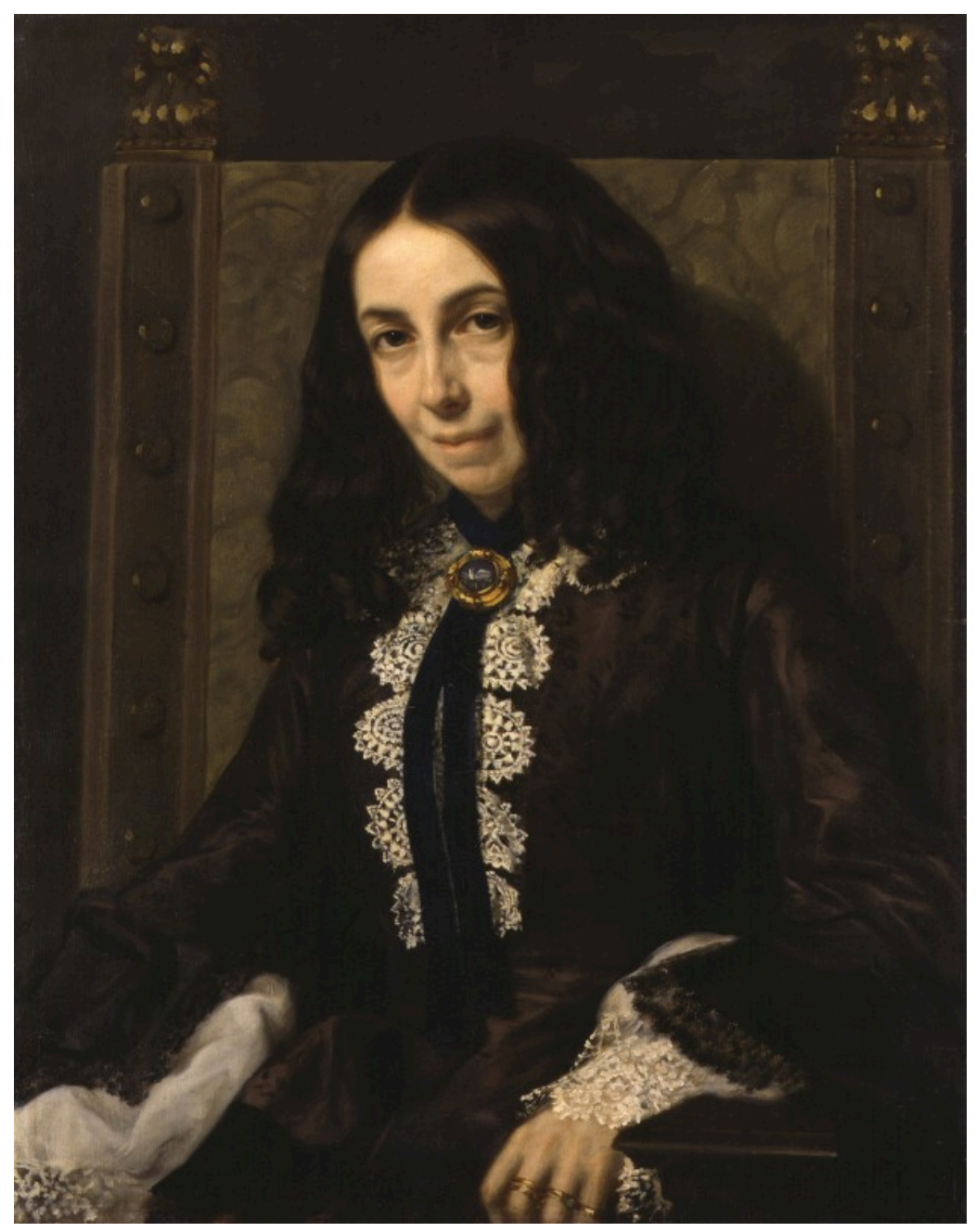

Figure 15.

Michele Gordigiani, Elizabeth Barrett Browning, 1858, oil on canvas, $73.7 \times 58.4 \mathrm{~cm}$. Collection of the National Portrait Gallery, London (NPG 1899). Digital image courtesy of National Portrait Gallery.

As feminist and ecocritical scholars have recently elaborated, human bodies can be understood as simultaneously material and social, produced through unceasing interaction. Nancy Tuana's notion of viscous porosity recognizes that living and non-living entities can be understood as bounded, but that such boundaries are porous and malleable. Her investigation reveals how bodies "are neither fixed nor inert, but fluid and emergent". $\underline{70}$ Barrett Browning's body exemplifies this concept. Both her illness and the treatments she experienced acted upon her flesh, as did substances in her physical environment. Clean air attracted the Brownings to Italy, where Hosmer met them and executed the cast. Furthermore, the vitality of Barrett Browning's public persona contrasts with-and depends upon-the frailty of her body. Scholars have even gone so far as to suggest that her poor health was a precondition of her literary production, exempting her from the social 
commitments demanded of her peers. One recent biography summarizes that her "frail, disease-stricken, almost corpse-like body is central to her mythologisation". $\underline{71}$

Observers of Clasped Hands have claimed to witness Barrett Browning's frailty-and Robert Browning's strength-in the cast. For example, on the occasion of acquiring a bronze version in the 1920s, the Baylor University Bulletin described the sculpture as capturing "the thin, emaciated hand of Mrs. Browning, clasped by the strong sinewy hand of the poet". $\underline{72}$ In a recent biography of Hosmer, Kate Culkin recounts how "Robert's palm closes protectively around his wife's small, passive hand; delicate embroidery surrounds her tiny wrist". $\underline{73}$ In fact, Elizabeth Barrett Browning's hand is the same size if not slightly larger than that of this author, and her veins protrude no more than Robert Browning's do. The tendency to overestimate her frailty and his strength, and to privilege the presence of her body over his, illustrates the long-standing tradition of pathologizing women's bodies. The bronze casts actually attest to the equal status of the Brownings as subjects of this cast: the inscriptions on each of their wrists match the orientation of their hands, so that in order to read one after the other, a viewer must turn the cast over. Moreover, the possibility of reversing the position of the hands, of variously featuring one poet over the other, has accommodated their changing reputations. In the nineteenth century, Robert Browning's fame greatly exceeded that of his wife, but the twentieth century witnessed Elizabeth Barrett Browning's popularity soar, and several versions of Clasped Hands were collected specifically as portraits of her. $\underline{74}$

The Brownings' bodies were constitutive of their literary and social identities, just as they were constituted by both internal and external forces. The hands that the Brownings presented for casting were not sealed entities belonging only to themselves, but amalgams of flesh, interaction, and experience. In the making of Clasped Hands, further exchanges took place. The moldmaking process transferred heat and material across the porous boundaries of the Brownings' skin, just as the Brownings' hands acted upon the plaster. In addition to the exchange between the sculptural materials and their bodies, Clasped Hands captures the phenomenon of two bodies in contact with one another. Hosmer's body, too, participated in this network, applying oil and plaster, manipulating the mold and cast, and making additional copies. The casts continue to carry physical traces of these exchanges in substance as well as in form. Furthermore, the bodies of all other individuals who have come into contact with Clasped Hands-including that of this author-left physical marks, most clearly visible in the damaged surface of the original plaster cast but also present in the varying patinas of the bronze versions. 


\section{Hands}

In representing the Brownings' hands, Hosmer participated in a tradition of synecdochic portraiture that privileged hands for their association with human creativity and the sense of touch. In the nineteenth century, a rising celebrity culture and the Victorian passion for collecting converged on the hands of famous individuals, evident in the production of life and death casts as well as the zeal for amassing autographs. $\frac{75}{2}$ The hands of writers, in particular, garnered attention as the body parts responsible for literary production, and sculptures and autographs evoked for collectors the gesture of holding pen to paper. That viewers in the 1890s observed the Brownings' autographs on the first version of Clasped Hands suggests that, whether or not the poets actually inscribed their names into the plaster, such associations circulated around this sculpture. ${ }^{76}$ Hosmer herself affirmed the connection between Clasped Hands and handwriting in her 1896 speech, offering to donate letters she had received from the Brownings to accompany the sculpture. ${ }^{77}$ Yet in the act of clasping each other's hands, neither of the writers can pursue the act of writing, as Marcia Pointon has noted. $\frac{78}{}$ Instead, they grip each other, the intimate space of their palms hidden from view.

Clasped Hands, then, represents not just two body parts but the experience of touch. Rose Marie San Juan has outlined how "hands stand in for the sense of touch not as exclusive site nor point of origin" and "serve as a substitute for the body as a whole and for embodied experience itself". $\underline{79}$ Because Clasped Hands lacks a single privileged position and demands to be seen in different orientations, it enacts what San Juan has called "the duality of touch": neither Elizabeth Barrett Browning nor Robert Browning exclusively bestows touch, just as neither exclusively receives it. ${ }^{80}$ As with all physical encounters, both parties touch and are touched in equal measure, each experience dependent on the other. This phenomenon extends beyond the Brownings' contact with one another to their interactions with Hosmer and the setting plaster. Just as subjects, artists, and materials acted upon one another, they all received each other's actions in turn. Reassigning agency across the network of participants thus demands a similar reassignment of passivity: to touch is to be touched. This mutual exchange defines the process of creating a life cast.

Two hands holding each other materialize a social experience of identity, otherness, and intimacy. Feminist theorist and scholar of science studies Karen Barad describes the moment experienced by the Brownings and captured by Hosmer: "When two hands touch, there is a sensuality of the flesh, an exchange of warmth, a feeling of pressure, of presence, a proximity of otherness that brings the other nearly as close as oneself. Perhaps closer". For Barad, two hands touching causes each individual to recognize "an 
infinity of others" and even "the otherness of the self", to others but also to

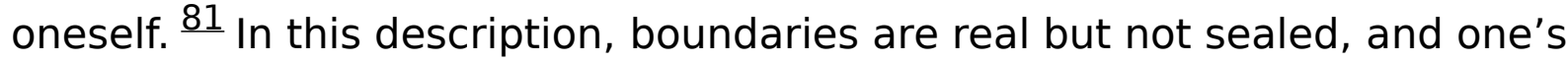
own body can be revealed to be not only one's own. The intertwining of the Brownings' hands projects the sensual meaning invoked by Barad, especially in light of the Brownings' romantic relationship. Absent this context, however, such a gesture might also be interpreted as transactional, as in two hands shaking upon achieving professional agreement. In both instances, the gesture embodies social experiences. Clasped Hands plays with this phenomenon, as the mold-making process eliminates any distinction between the two hands and unites them in a single negative space.

Barad's account of the proximity involved in two hands touching recalls Barrett Browning's interest in "the sense of nearness involved" in daguerreotypes. Where the act of clasping hands brings near another individual, another body, and even the experience of otherness, both photographs and life casts bring near absent individuals through the material processes of their creation. Hosmer's Clasped Hands, then, simultaneously displays nearness in the position of the Browning's hands and performs nearness through the casting process, making it an exemplary object through which to understand the complex relationships among bodies and materials involved in life casting. In both the 1853 interaction between the Brownings and the ongoing exchanges between Clasped Hands and its viewers, bringing near was not and is not a straightforward act but a multifaceted negotiation. The Brownings' bodies, themselves porous entities, came together not harmoniously but in a state of tension and pressure. The Brownings' interlocked hands are not simply present within the plaster cast; rather, they are brought near by the interactions among many human and material agents, including flesh, oil, plaster, sand, bronze, and chemicals. Although artistic choices are typically downplayed in discussions around cast sculpture, the sculptor, too, played a critical role in this cast's creation and success. Recognizing these exchanges replaces an illusion of presence-of contingency and conjunction-with a sense of nearness.

These issues culminate in the edges of Clasped Hands: the cuffs of the Brownings' sleeves. The scalloped cuff on Elizabeth Barrett Browning's wrist and the barrel cuff on Robert Browning's must have been modeled rather than cast, because casting clothing would have damaged it, and the carefully articulated cuffs are more iconographic than realistic. The sleeves are too thick, too unwrinkled, and too regular to represent actual garments. Instead, the cuffs are Hosmer's most obvious intervention in the casting process, products of an artistic choice that makes a critical contribution to the resulting sculpture. The cuffs act as a limit to the Brownings' exposed skin, almost in a gesture of propriety, insisting that the Brownings are fully clothed out of view. They also help identify the hands according to gender. The cuffs further communicate that Clasped Hands is a complete, independent work of 
art, as opposed to a preparatory study for a larger sculpture. Ultimately, the cuffs frame the representational part of the sculpture, providing a boundary between the direct rendering of skin and the artificial flat surface of the severed wrist, on which the inscriptions were added. Indeed, the casting process could not achieve a closed entity: the sections of the wrists correspond to openings in the mold, through which the Brownings arms extended beyond the setting plaster. The flat surfaces make no claim to display the tendons, blood vessels, and bones within the Brownings' arms, but instead make visible the complex process of casting and the hand of the artist.

\section{Footnotes}

1 Elizabeth Barrett Browning to Mary Russell Mitford, 7 December 1843, Browning Collection, Margaret Clapp Library, Wellesley College, Wellesley, MA.

2 See James Joopes (ed.), Peirce on Signs: Writings on Semiotic (Chapel Hill, NC: University of North Carolina Press, 1991).

3 Susan Sontag, On Photography (New York: Picador, 1973), 154.

$4 \quad$ Rosalind Krauss, “Notes on the Index: Seventies Art in America”, October 3 (1977), 80.

$\underline{5}$ Robin Kelsey and Blake Stimson (eds.), The Meaning of Photography (Williamstown, MA: Sterling and Francine Clark Art Institute, 2008), 3-56. See also Tom Gunning, "What's the Point of an Index? or, Faking Photographs", Nordicom Review 25, nos 1-2 (2004): 39-49; and Martin Lefebvre, "The Art of Pointing: On Peirce, Indexicality, and Photographic Images", in James Elkins (ed.), Photography Theory (New York: Routledge, 2007): 220-244.

6 See Patrick Crowley, "Roman Death Masks and the Metaphorics of the Negative", Grey Room 64 (2016): 64-103; Louis Kaplan, "Photograph/Death Mask: Jean-Luc Nancy's Recasting of the Photographic Image", Journal of Visual Culture 9, no. 1 (2010): 45-62; and Rebecca Wade, Domenico Brucciani and the Formatori of Nineteenth-Century Britain (London: Bloomsbury, 2018), particularly 75-93 and 118-124.

7 See Jean-François Corpataux, "Life Body Moulding and Maternal Devotion in Marcello's Studio", in Rune Fredericksen and Eckart Marchand (eds.), Plaster Casts: Making, Collecting, and Displaying from Classical Antiquity to the Present (Berlin: De Gruyter, 2010), 307-318; Hanna Rose Shell, “Casting Life, Recasting Experience: Bernard Palissy's Occupation between Maker and Nature", Configurations 12, no. 1 (2004): 1-40; and Pamela H. Smith and Tonny Beentjes, "Nature and Art, Making and Knowing: Reconstructing Sixteenth-Century Life-Casting Techniques", Renaissance Quarterly 63, no. 1 (Spring 2010): 128-179.

8 The original plaster cast resides at the Schlesinger Library of the Radcliffe Institute at Harvard University. The second plaster version is in the collection of the National Museum of Women in the Arts. The bronze versions belong to the Armstrong-Browning Library at Baylor University, the Boston Public Library, the Metropolitan Museum of Art, the National Gallery of Art (Washington, DC), the National Portrait Gallery (London), the Newark Museum, the Saint Louis Art Museum, and Wellesley College.

9 See Melissa Dabakis, A Sisterhood of Sculptors: American Artists in Nineteenth-Century Rome (University Park, PA: Pennsylvania State University Press, 2014); Martina Droth, Jason Edwards, and Michael Hatt (eds.), Sculpture Victorious: Art in an Age of Invention, 1837-1901 (New Haven, CT: Yale Center for British Art, 2014); and Patricia Pulham, "Marmoreal Sisterhoods: Classical Statuary in Nineteenth-Century Women's Writing", 19: Interdisciplinary Studies in the Long Nineteenth Century 22 (2016).

10 See Margo Lois Beggs, "Harriet Hosmer (1830-1908): Fame, Photography, and the American 'Sculptress'" (PhD diss., University of Toronto, 2013); Cornelia Crow Carr (ed.), Harriet Hosmer: Letters and Memories (London: John Lane, 1913); Patricia Cronin, Harriet Hosmer: Lost and Found (New York: Charta, 2009); Kate Culkin, Harriet Hosmer: A Cultural Biography (Amherst, MA: University of Massachusetts Press, 2010); Melissa Dabakis, “'The Eccentric Life of a Perfectly Emancipated Female': Harriet Hosmer's Early Years in Rome", in Thayer Tolles (ed.), Perspectives on American Sculpture Before 1925 (New York: Metropolitan Museum of Art, 2003), 24-43; Vivien Green Fryd, "The 'Ghosting' of Incest and Female Relations in Harriet Hosmer's Beatrice Cenci", Art Bulletin 88, no. 2 (2006): 292-309; Gabrielle Gopinath, "Harriet Hosmer and the Feminine Sublime", Oxford Art Journal 28, no. 1 (2005): 63-81; Joseph Leach, "Harriet Hosmer: Feminist in Bronze and Marble", Feminist Art Journal 5, no. 2 (1976): 9-13, 44-45; Gail Marshall, "Harriet Hosmer and the Classical Inheritance", Forum for Modern Language Studies 39, no. 2 (2003): 202-213; Dolly Sherwood, Harriet Hosmer: American Sculptor, 1830-1908 (Columbia, MO: University of Missouri Press, 1991); and Lilian Whiting, "Harriet Goodhue Hosmer", in Women Who Have Ennobled Life (Philadelphia, PA: Union Press, 1915), 209-234.

11 The two bronze sculptures are The Mermaid's Castle, 1893, Larchmont Manor Park Society, and Thomas Hart Benton, 1860 s, City of St. Louis, Department of Parks, Recreation, and Forestry.

12 Nathaniel Hawthorne, The Marble Faun or, The Romance of Monte Beni (Boston, MA: Ticknor and Fields, 1860 ), 154.

13 Dabakis, “'The Eccentric Life of a Perfectly Emancipated Female'”, 30. 
14 Nicolas Penny, "Sculpture and Privacy", in Peter Parshall (ed.), The Darker Side of Life: Arts of Privacy, 1850-1900 (Washington, DC: National Gallery of Art, 2009), 138.

15 Marcia Pointon, "Casts, Imprints, and the Deathliness of Things: Artifacts at the Edge", Art Bulletin 96, no. 2 (2014), 170.

16 Pointon, "Casts, Imprints, and the Deathliness of Things", 188.

17 Charles Knight, "On Plaster Figures and Casts", Penny Magazine of the Society for the Diffusion of Useful Knowledge 7, no. 419 (13 October 1838), 394; William Ordway Partridge, Techniques of Sculpture (Boston, MA: Ginn and Company, 1895), 79.

18 "How to Make Plaster Casts from Life", Art Amateur (New York) 32, no. 5 (April 1895), 143.

19 Lucy M. Mitchell, "Plaster in Sculpture: Its Value as a Medium for Copying the Old Masters", New York Times, 20 April 1885.

20 R.B. Thurston, "Harriet G. Hosmer", in James Parton, et al. (eds.), Eminent Women of the Age: Being Narratives of the Lives and Deeds of the Most Prominent Women of the Present Generation (Hartford, CT: S. M. Betts \& Co., 1868 ), 570.

21 For a detailed account of plaster in nineteenth-century, particularly French, sculpture studios, see Catherine Chevillot, "Nineteenth-Century Sculpteurs and Mouleurs: Developments in Theory and Practice", in Sébastien Clerbois and Martina Droth (eds.), Revival and Invention: Sculpture through its Material Histories (Bern: Peter Lang, 2011), 201-230.

22 Harriet Hosmer, "Notes on the Casting of the Clasped Hands of Robert and Elizabeth Barrett Browning", 1896, Harriet Goodhue Hosmer Papers, Arthur and Elizabeth Schlesinger Library on the History of Women in America, Radcliffe Institute for Advanced Study, Harvard University.

$\underline{23}$ Penny, "Sculpture and Privacy", 138.

24 Knight, "On Plaster Figures and Casts", 394; Frank Forrest Frederick, Plaster Casts and How They Are Made (New York: W.T. Comstock, 1899), 73; "How to Make Plaster Casts from Life", Art Amateur, 143. Vaseline, an American brand of petroleum jelly, was not patented until 1872.

25 Frederick, Plaster Casts and How They Are Made, 74.

26 Frederick, Plaster Casts and How They Are Made, 75.

27 Benjamin Robert Haydon, Life of Benjamin Robert Haydon, Historical Painter, from His Autobiography and Journals, edited by Tom Taylor (London: Longman, Brown, Green, and Longmans, 1853), 148-150.

28 Melvin J. Wachowiak, Basiliki Vicky Karas, and Robert E. Baltrusch, "Reconstruction of a 19th Century Plaster Piece Mold and Recreation of a Casting", Quality Digest (23 May 2010): https://www.qualitydigest.com/inside/cmsc-article/ reconstruction-19th-century-plaster-piece-mold-and-recreation-casting.html. See also Karen Lemmey, "From Skeleton to Skin: The Making of the Greek Slave(s)", Nineteenth-Century Art Worldwide 15, no. 2 (2016), 50.

29 Both Nicholas Penny and Marcia Pointon assume that Robert Browning's hand and Elizabeth Barrett Browning's hand would have been cast separately. This author has found no indication that this would be the case, and close examination of the plaster supports the view that their hands were cast together. Penny, "Sculpture and Privacy", 131; Pointon, "Casts, Imprints, and the Deathliness of Things", 188.

30 Knight, "On Plaster Figures and Casts", 394-395.

31 "How to Make Plaster Casts from Life", Art Amateur, 143.

32 Frederick, Plaster Casts and How They Are Made, 75.

33 Mitchell, "Plaster in Sculpture".

34 "How to Make a Life-Mask", Literary Digest 18, no. 6 (1899): 173.

35 Frederick, Plaster Casts and How They Are Made, 74.

36 Mitchell, "Plaster in Sculpture".

37 "How to Make Plaster Casts from Life", Art Amateur, 143.

38 "Pertaining to Women", Boston Sunday Herald, 30 August 1891.

39 In 1894, a flurry of newspaper articles documented the artist giving a version of Clasped Hands-purportedly the original-to the Art Institute of Chicago, something Hosmer stated she intended to do in her 1896 speech. Although the museum has no record of this gift and no version remains in its collection, these articles reference the wrist inscriptions: "The Art Institute of Chicago has received a gift from Harriet Hosmer of the cast she made in 1853 of the clasped hands of Robert Browning and his wife. ... The autograph of 'Elizabeth Barrett Browning, Rome, May 1853', is on the wrist of one; 'Robert Browning, Rome' on the wrist of the other. Miss Hosmer refused in England an offer of $£ 5000$ for this unique cast". "Personal", New York Tribune, 29 June 1894. See also Joseph L. Curran, Jr., correspondence, Harriet Goodhue Hosmer Papers, Watertown Free Public Library.

40 Mitchell, "Plaster in Sculpture".

41 Hosmer, "Notes on the Clasped Hands", Hosmer Papers, Schlesinger Library.

42 Harriet Hosmer to Wayman Crow, 14 June 1858, in Carr, Letters and Memories, 124.

43 Robert Browning to Harriet Hosmer, 16 November 1854, in Carr, Letters and Memories, 46. 
44 For more on color, race, and sculptural materials in the nineteenth century, see Charmaine Nelson, Color of Stone: Sculpting the Black Female Subject in Nineteenth-Century America (Minneapolis, MN: University of Minnesota Press, 2007), and Luke Syson et al., Like Life: Sculpture, Color, and the Body (New York: Metropolitan Museum of Art; New Haven, CT: Yale University Press, 2018).

45 See Partridge, Techniques of Sculpture, 86.

46 See "How to Obtain a Fine Patina on Bronze Statues", Scientific American 22, no. 7 (12 February 1870), 104.

47 See "Greenish-Brown Patina for Brass and Bronze", Scientific American 58, no. 4 (28 January 1888), 57.

48 See Nicholas Penny, The Materials of Sculpture (New Haven, CT: Yale University Press, 1993), 219-256; and Marjorie Trusted (ed.), The Making of Sculpture: The Materials and Techniques of European Sculpture (London: V\&A Publications, 2007).

49 See Michael Edward Shapiro, Bronze Casting and American Sculpture (Newark, DE: University of Delaware Press, 1985), 15-59, 165-176.

50 Theodore Finkelston, “'Old Bullion' Bronzed: Business's Monument to Western Opportunity”, Gateway Heritage 11, no. 2 (Fall 1990), 53.

51 See Partridge, Techniques of Sculpture, 88-90.

52 "Casting Bronze Statues", Stone 10, no. 4 (1 March 1895), 355.

53 George Simonds, "Artistic Bronze Casting", Journal of the Society of Arts (London) 34 (20 November 1885), 246.

54 For a popular account of Italian sculptural casters in London, see Arthur Conan Doyle, "The Adventure of the Six Napoleons", Strand Magazine (London) 27, no. 161 (May 1904): 483-495.

55 Simonds, "Artistic Bronze Casting", 258.

56 See Sherwood, Harriet Hosmer, 218-223.

57 Harriet Hosmer, "The Process of Sculpture", Atlantic Monthly 14, no. 86 (December 1864), 734.

58 Hosmer, "The Process of Sculpture", 735.

59 Hosmer, "The Process of Sculpture", 736.

60 "Most Famous of American Women Sculptors: Miss Harriet Hosmer of Watertown”, Boston Daily Globe, 1 March 1908.

61 Elizabeth Barrett Browning to Isa Blagden, 4-8 May 1854, quoted in Philip Kelley and Sandra Donaldson (eds.), Florentine Friends: The Letters of Elizabeth Barrett Browning and Robert Browning to Isa Blagden, 1850-1861 (Waco, TX: Wedgestone Press, 2009), 51.

62 Thomas Crawford to Louisa Crawford, 5 July 1854, Thomas Crawford Papers, Archives of American Art, Smithsonian Institution, Washington, DC.

63 See Dabakis, “'The Eccentric Life of a Perfectly Emancipated Female'”. Some of Hosmer's sculpting tools survive in the Harriet Goodhue Hosmer Papers at the Watertown Free Public Library.

64 Hosmer, "Notes on the Clasped Hands", Hosmer Papers, Schlesinger Library.

65 For a discussion of art, reproduction, and intellectual property, including body casts and the emergence of copyright, see Katie Scott, Becoming Property: Art, Theory, and Law in Early Modern France (New Haven, CT: Yale University Press, 2018), especially 211-239.

66 "How to Make a Life-Mask", 173.

67 Harvey Young, Embodying Black Experience: Stillness, Critical Memory, and the Black Body (Ann Arbor, MI: University of Michigan Press, 2010).

68 "How to Make Plaster Casts from Life", Art Amateur, 143.

69 Scholars and physicians are still engaged in diagnosing her illness. For an account of her symptoms and treatments, as well as modern medical analyses, see D.A.B. Young, "The Illnesses of Elizabeth Barrett Browning", British Medical Journal 298 (1989): 439-443.

70 Nancy Tuana, "Viscous Porosity: Witnessing Katrina", in Stacey Alaimo and Susan Hekman (eds.), Material Feminisms (Bloomington, IN: Indiana University Press, 2008), 189.

71 Simon Avery and Rebecca Stott, Elizabeth Barrett Browning (London: Routledge, 2014), 40.

72 A.J. Armstrong (ed.), "Baylor University's Browning Collection and Other Browning Interests", Baylor Bulletin 30, no. 4 (Waco, TX: Baylor University, 1927), 15-16.

73 Culkin, Hosmer, 38.

74 See Hannah French, "The Browning Collection of the Wellesley College Library", Browning Newsletter 6 (January 1971): 28-37. I am grateful to Anne Higonnet for bringing this history to my attention.

75 See Josh Lauer, "Traces of the Real: Autographomania and the Cult of the Signers in Nineteenth-Century America", Text and Performance Quarterly 27, no. 2 (2007): 143-163; Pamela Corpron Parker, "Woman of Letters: Elizabeth Gaskell's Autograph Collection and Victorian Celebrity", in Maureen Daly Goggin and Beth Fowkes Tobin (eds.), Material Women, 1750-1950: Consuming Desires and Collecting Practices, 265-278 (Farnham: Ashgate, 2009); and Penny, "Sculpture and Privacy", 137-147.

76 "Pertaining to Women", Boston Sunday Herald. 


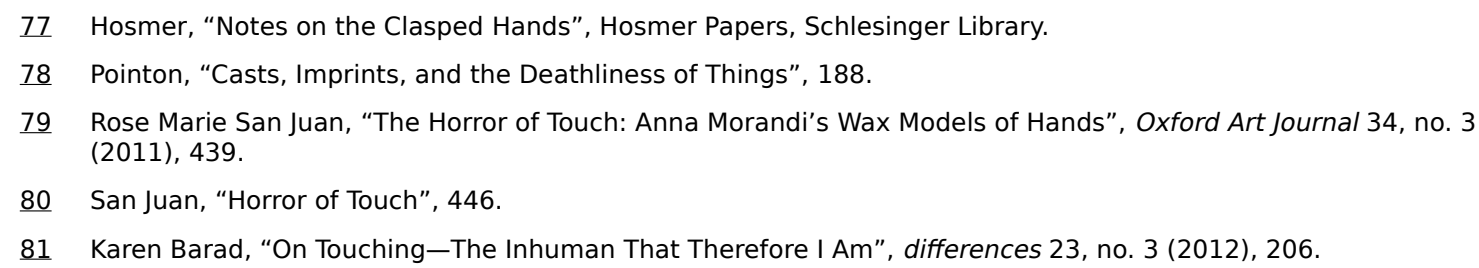

\section{Bibliography}

Armstrong, A.J. (ed.) (1927) "Baylor University's Browning Collection and Other Browning Interests". Baylor Bulletin 30, no. 4. Waco, TX: Baylor University.

Art Amateur (1895) “How to Make Plaster Casts from Life". Art Amateur (New York) 32, no. 5 (April): 143.

Avery, S. and Stott, R. (2014) Elizabeth Barrett Browning. London: Routledge.

Barad, K. (2012) "On Touching-The Inhuman That Therefore I Am". differences 23, no. 3: 206-223.

Beggs, M.L. (2013) “Harriet Hosmer (1830-1908): Fame, Photography, and the American 'Sculptress'”. PhD diss., University of Toronto.

Boston Daily Globe (1908) "Most Famous of American Women Sculptors: Miss Harriet Hosmer of Watertown”. Boston Daily Globe (1 March).

Boston Sunday Herald (1891) "Pertaining to Women". Boston Sunday Herald (30 August).

Browning Collection. Margaret Clapp Library, Wellesley College, Wellesley, MA.

Carr, C.C. (ed.) (1913) Harriet Hosmer: Letters and Memories. London: John Lane.

Chevillot, C. (2011) “Nineteenth-Century Sculpteurs and Mouleurs: Developments in Theory and Practice”. In Sébastien Clerbois and Martina Droth (eds.), Revival and Invention: Sculpture through its Material Histories. Bern: Peter Lang, 201-230.

Corpataux, J. (2010) “Life Body Moudling and Maternal Devotion in Marcello's Studio". In Rune Fredericksen and Eckart Marchand (eds.), Plaster Casts: Making, Collecting, Displaying from Classical Antiquity to the Present. Berlin: De Gruyter, 307-318.

Crawford, Thomas. Papers. Archives of American Art, Smithsonian Institution, Washington, DC.

Cronin, P. (2009) Harriet Hosmer: Lost and Found. New York: Charta.

Crowley, P. (2016) "Roman Death Masks and the Metaphorics of the Negative". Grey Room 64: 64-103.

Culkin, K. (2010) Harriet Hosmer: A Cultural Biography. Amherst, MA: University of Massachusetts Press.

Dabakis, M. (2003) “'The Eccentric Life of a Perfectly Emancipated Female': Harriet Hosmer's Early Years in Rome”. In Thayer Tolles (ed.), Perspectives on American Sculpture Before 1925. New York: Metropolitan Museum of Art, 24-43.

Dabakis, M. (2014) A Sisterhood of Sculptors: American Artists in Nineteenth-Century Rome. University Park, PA: Pennsylvania State University Press.

Doyle, A.C. (1904) “The Adventure of the Six Napoleons". Strand Magazine (London) 27, no. 161 (May 1904): 483-495.

Droth, M., Edwards, J., and Hatt, M. (eds.) (2014) Sculpture Victorious: Art in an Age of Invention, 1837-1901. New Haven, CT: Yale Center for British Art.

Finkelston, T. (1990) “'Old Bullion' Bronzed: Business's Monument to Western Opportunity”. Gateway Heritage 11, no. 2: 53.

French, H. (1971) "The Browning Collection of the Wellesley College Library". Browning Newsletter 6 (January): 28-37.

Frederick, F.F. (1899) Plaster Casts and How They Are Made. New York: W.T. Comstock.

Fryd, V.G. (2006) “The 'Ghosting' of Incest and Female Relations in Harriet Hosmer's Beatrice Cenci”. Art Bulletin 88, no. 2: 292-309.

Gopinath, G. (2005) "Harriet Hosmer and the Feminine Sublime”. Oxford Art Journal 28, no. 1: 63-81.

Gunning, T. (2004) "What's the Point of an Index? or, Faking Photographs". Nordicom Review 25, nos. 1-2: 39-49.

Hawthorne, N. (1860) The Marble Faun or, The Romance of Monte Beni. Boston, MA: Ticknor and Fields.

Haydon, B.R. (1853) Life of Benjamin Robert Haydon, Historical Painter, from His Autobiography and Journals. Edited by Tom Taylor. London: Longman, Brown, Green, and Longmans.

Hosmer, H.G. Papers. Arthur and Elizabeth Schlesinger Library on the History of Women in America, Radcliffe Institute for Advanced Study at Harvard University, Cambridge, MA.

Hosmer, H.G. Papers. Watertown Free Public Library, Watertown, MA.

Hosmer, H.G. (1864) "The Process of Sculpture". Atlantic Monthly 14, no. 86: 734-737.

Joopes, J. (ed.) (1991) Peirce on Signs: Writings on Semiotic. Chapel Hill, NC: University of North Carolina Press.

Kaplan, L. (2010) “Photography/Death Mask: Jean-Luc Nancy's Recasting of the Photographic Image”. Journal of Visual Culture 9, no. 1: 45-62. 
Kelley, P. and Donaldson, S. (eds.) (2009) Florentine Friends: The Letters of Elizabeth Barrett Browning and Robert Browning to Isa Blagden, 1850-1861. Waco, TX: Wedgestone Press.

Kelsey, R. and Stimson, B. (eds.) (2008) The Meaning of Photography. Williamstown, MA: Sterling and Francine Clark Art Institute.

Knight, C. (1838) "On Plaster Figures and Casts". Penny Magazine of the Society for the Diffusion of Useful Knowledge 7, no. 419 (13 October): 394-395.

Krauss, R. (1977) “Notes on the Index: Seventies Art in America”. October 3: 68-81.

Lauer, J. (2007) "Traces of the Real: Autographomania and the Cult of the Signers in Nineteenth-Century America". Text and Performance Quarterly 27, no. 2: 143-163.

Leach, J. (1976) "Harriet Hosmer: Feminist in Bronze and Marble". Feminist Art Journal 5, no. 2: 9-13, 44-45.

Lefebvre, M. (2007) “The Art of Pointing: On Peirce, Indexicality, and Photographic Images". In James Elkins (ed.), Photography Theory. New York: Routledge, 220-244.

Lemmey, K. (2016) "From Skeleton to Skin: The Making of the Greek Slave(s)". Nineteenth-Century Art Worldwide 15, no. 2. http://www.19thc-artworldwide.org/summer16/lemmey-on-from-skeleton-to-skin-the-making-of-the-greek-slave.

Literary Digest (1899) “How to Make a Life-Mask". Literary Digest 18, no. 6: 173.

Marshall, G. (2003) "Harriet Hosmer and the Classical Inheritance”. Forum for Modern Language Studies 39, no. 2: $202-213$.

Mitchell, L.M. (1885) "Plaster in Sculpture: Its Value as a Medium for Copying the Old Masters". New York Times (20 April).

Nelson, C. (2007) Color of Stone: Sculpting the Black Female Subject in Nineteenth-Century America. Minneapolis, MN: University of Minnesota Press.

New York Tribune (1894) "Personal". New York Tribune (29 June).

Partridge, W.O. (1895) Techniques of Sculpture. Boston, MA: Ginn and Company.

Parton, J. et al. (1868) Eminent Women of the Age: Being Narratives of the Lives and Deeds of the Most Prominent Women of the Present Generation. Hartford, CT: S. M. Betts \& Co.Parker, P.C. (2009) “Woman of Letters: Elizabeth Gaskell's Autograph Collection and Victorian Celebrity". In Maureen Galy Goggin and Beth Fowkes Tobin (eds.), Material Women, 1750-1950: Consuming Desires and Collecting Practices. Farnham: Ashgate, 265-278.

Penny, N. (1993) The Materials of Sculpture. New Haven, CT: Yale University Press.

Penny, N. (2009) "Sculpture and Privacy". In Peter Parshall (ed.), The Darker Side of Light: Arts of Privacy, 1850-1900. Washington, DC: National Gallery of Art, 128-151.

Pointon, M. (2014) "Casts, Imprints, and Deathliness of Things: Artifacts at the Edge". Art Bulletin 96, no. 2: 170-195.

Pulham, P. (2016) “Marmoreal Sisterhoods: Classical Statuary in Nineteenth-Century Women's Writing". 19: Interdisciplinary Studies in the Long Nineteenth Century 22. doi:10.16995/ntn.763.

San Juan, R.M. (2011) “The Horror of Touch: Anna Morandi's Wax Models of Hands”. Oxford Art Journal 34, no. 3: $433-447$.

Scientific American (1870) "How to Obtain a Fine Patina on Bronze Statues”. Scientific American 22, no. 7 (12 February): 104.

Scientific American (1888) "Greenish-Brown Patina for Brass and Bronze". Scientific American 58, no. 4 (28 January): 57.

Scott, K. (2018) Becoming Property: Art, Theory, and Law in Early Modern France. New Haven, CT: Yale University Press.

Shapiro, M.E. (1985) Bronze Casting and American Sculpture. Newark, DE: University of Delaware Press.

Shell, H.R. (2004) "Casting Life, Recasting Experience: Bernard Palissy's Occupation between Maker and Nature".

Configurations 12, no. 1: 1-40.

Sherwood, D. (1991) Harriet Hosmer: American Sculptor, 1830-1908. Columbia, MO: University of Missouri Press.

Simonds, G. (1885) "Artistic Bronze Casting". Journal of the Society of Arts (London) 34 (20 November): 245-258.

Smith, P.H. and Beentjes, T. (2010) "Nature and Art, Making and Knowing: Reconstructing Sixteenth-Century Life-Casting Techniques". Renaissance Quarterly 63, no. 1: 128-179.

Sontag, S. (1973) On Photography. New York: Picador.

Stone (1895) "Casting Bronze Statues". Stone 10, no. 4 (1 March): 355-356.

Syson, L. et al. (2018) Like Life: Sculpture, Color, and the Body. New York: Metropolitan Museum of Art; New Haven, CT: Yale University Press.

Thurston, R.B. (1868) “Harriet G. Hosmer". In James Parton, et al. (eds.), Eminent Women of the Age: Being Narratives of the Lives and Deeds of the Most Prominent Women of the Present Generation. Hartford, CT: S. M. Betts \& Co.

Trusted, M. (ed.) (2007) The Making of Sculpture: The Materials and Techniques of European Sculpture. London: V\&A Publications.

Tuana, N. (2008) “Viscous Porosity: Witnessing Katrina”. In Stacey Alaimo and Susan Hekman (eds.), Material Feminisms. Bloomington, IN: Indiana University Press, 188-213.

Wade, R. (2018) Domenico Brucciani and the Formatori of Nineteenth-Century Britain. London: Bloomsbury.

Whiting, L. (1915) Women Who Have Ennobled Life. Philadelphia, PA: Union Press.

Wachowiak, M.J., Karas, B.V., and Baltrusch, R.E. (2010) “Reconstruction of a 19th Century Plaster Piece Mold and Recreation of a Casting". Quality Digest (23 May). https://www.qualitydigest.com/inside/cmsc-article/reconstruction-19th-century-plasterpiece-mold-and-recreation-casting.html. 
Young, D.A.B. (1989) "The Illness of Elizabeth Barrett Browning”. British Medical Journal 298: 439-443.

Young, H. (2010) Embodying Black Experience: Stillness, Critical Memory, and the Black Body. Ann Arbor, MI: University of Michigan Press. 


\section{Licensing}

The Publishers of British Art Studies are committed to supporting scholarship on British art and architecture of all periods. This publication is made available free of charge at https://www.britishartstudies.ac.uk. We ask users to identify the use of materials made available through this website and to provide an appropriate credit to the to the author and the publication, so that others may find and use our resources.

Except where otherwise noted, this work is licensed under a Creative Commons Attribution-NonCommercial 2.0 UK: England \& Wales Licence (CC BY-NC 2.0 UK). To view a copy of this license, visit https://creativecommons.org/licenses/by-nc/2.0/uk/ or send a letter to Creative Commons, PO Box 1866, Mountain View, CA 94042, USA.

The Publishers fully support the protection of intellectual property and are committed to complying with, and strictly adhering to, all applicable copyright law. In many cases, copyright or other proprietary rights may be held by individuals or entities other than, or in addition to, the Publishers. If a work or a photographic image is still protected by copyright, you must cite the relevant copyright information when using the image and comply with all other terms or restrictions that may be applicable to that material.

In some cases, exceptions to copyright that permit limited use of protected works without the permission of the copyright owner may have be applied. We are confident that we have carried out due diligence in our use of copyrighted material as required, but we apologise for any inadvertent infringement of rights.

Digital copies of resources are made accessible for research for one of the following reasons:

- they are in the public domain;

- the rights are owned by the Publishers;

- we make them accessible under an exception or limitation to UK copyright law, as outlined in the Copyright, Designs and Patents Act 1988 (as amended);

- we have permission to make them accessible;

- or, there are no known restrictions on use.

If you believe that we have made a mistake and wish for your material to be removed from our site, please contact us at copyright@paul-mellon-centre.ac.uk.

Please include the following information with your request:

- Name and contact information, including email address and phone number.

- Identification of the resource for consideration of removal. Providing URLs in your communication will help us locate content quickly.

- The reason for the request.

The Publishers respond promptly, normally within 21 business days. We may remove the resource from our site while we assess the validity of the request. Upon completion of the assessment, we will take appropriate action and communicate that action to you. 